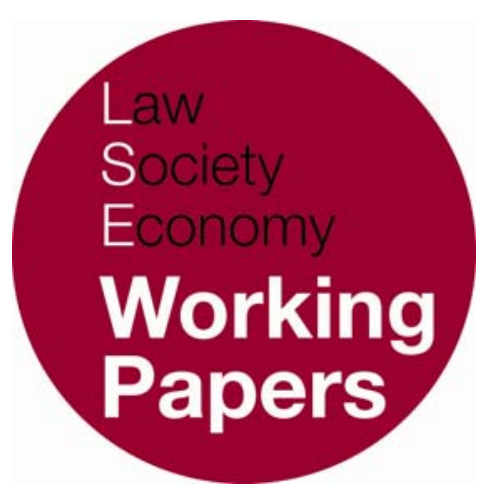

\title{
Law Through Practice: London and Liverpool Commodity Markets c.1820-1975
}

\author{
Ross Cranston
}

LSE Law, Society and Economy Working Papers 14/2007

London School of Economics and Political Science

Law Department

This paper can be downloaded without charge from LSE Law, Society and Economy Working Papers at: www.lse.ac.uk/collections/law/wps/wps.htm and the Social Science Research Network electronic library at: http://ssrn.comabstract $=1021952$.

(C) Ross Cranston. Users may download and/or print one copy to facilitate their private study or for non-commercial research. Users may not engage in further distribution of this material or use it for any profit-making activities or any other form of commercial gain. 


\title{
Law Through Practice: London and Liverpool Commodity Markets c.1820-1975
}

\author{
Ross Cranston ${ }^{*}$
}

\begin{abstract}
Although now forgotten, organized markets in commodities like grain, cotton, sugar, coffee and spices became firmly established in London and Liverpool in the nineteenth century. These markets were stimulated by the rising volume of international trade, as Britain became the first industrial nation, a major importer of these commodities and a centre for organising their distribution elsewhere, especially in Europe. The story of these markets, and the role of law in their operation, is fascinating in itself. However, it also enables us to test some ideas about markets against the reality of what were, for a time, some of the leading physical and futures markets in commodities in the world. The first part of this article outlines key features in the organisation and operation of these markets; the second part concentrates on the central, if uncelebrated, functions of clearing and settling transactions in these markets; and finally there is a discussion of market integrity and the role of law in curbing abuse.
\end{abstract}

\section{INTRODUCTION}

In his study of Civilisation and Capitalism, Fernand Braudel writes of the establishment of direct and regular maritime contact between Genoa and Bruges after 1297 and how this symbolised the transformation of large-scale commerce in the early fourteenth century. 'Merchandise was beginning to travel alone: its movements between Italy and the Netherlands, the two poles of the European economy, were controlled from a distance by written correspondence, and there was no longer any need for merchants to meet and discus matters half-way.'1 Subsequently came the fairs, international wholesale markets where goods were sold and accounts extinguished by set-off, 'debts met and cancelled each other out,

\footnotetext{
* Centennial Professor of Law, London School of Economics and Political Science.

${ }^{1}$ F. Braudel, The Structure of Everyday Life (London: Collins, 1981) 419.
} 
melting like snow in the sun...' ${ }^{2}$ Then followed the Piacenza fair, mainly run by Genoese banchierei di conto: without merchandise and little cash, masses of bills of exchange were liquidated, representing the entire wealth of Europe. ${ }^{3}$ Markets were no longer simply places to trade goods but where contractual claims could be settled.

The setting for this study is not Italy in the fourteenth century but, rather the commodity markets in London and Liverpool in England in the nineteenth and early twentieth centuries. Despite considerable gaps there is a rich seam of business archives which have hardly ever been exploited by lawyers. ${ }^{4}$ The story of these markets, and the role of law in their operation, is fascinating in itself. However, it also enables us to test some ideas about markets against the reality of what were, for a time, some of the leading physical and futures markets in commodities in the world. The first part of this article outlines key features in the organisation and operation of these markets; the second part concentrates on the central, if uncelebrated, functions of clearing and settling transactions in these markets; and finally there is a discussion of market integrity and the role of law in curbing abuse. The crucial feature of dispute resolution through arbitration is left for another day.

\title{
MARKETS, BROKERS AND FUTURES
}

\begin{abstract}
They stood together, two solid middle-aged men, and together they watched the long line of masts and funnels in the Royal Albert Dock go sliding away. They were still in London, and no great distance from the buses and trams, the teashops and the pubs, yet all that London seemed to have disappeared long ago. Here was another city with streets and squares of dark water, a city of wharves and sheds, masts and funnels and cranes, barges, tugs, and lighters. Wherever you looked there appeared to be nothing but these things...'
\end{abstract}

Although now forgotten, organized markets in commodities like grain, cotton, sugar, coffee and spices became firmly established in London and Liverpool in the nineteenth century. These markets were stimulated by the rising volume of international trade, as Britain became the first industrial nation, a major importer of these commodities and a centre for organising their distribution elsewhere, especially in Europe. Added to that were the improvement in communications and the importance of Britain as a centre for shipping, finance and insurance. Local produce markets such as the corn exchanges in major cities and towns remained but were no longer isolated from international trends. World prices were struck as a result of numerous transactions on the London and Liverpool markets. Not only

2 F. Braudel, The Wheels of Commerce (London: Collins, 1982) 90-1.

3 ibid $91,94$.

${ }^{4}$ I have used the Guildhall Library of the City of London (GL), the Merseyside Maritime Museum, Liverpool (LMM) and the Liverpool Record Office (LRO).

5 J.B. Priestley, Angel Pavement (London: Heinemann, 1930). 
did they facilitate distribution through space with spot transactions for immediate delivery but as well distribution through time with forward and futures dealings. ${ }^{6}$ Futures transactions enabled the ultimate producers of commodities in various parts of the world, and the manufacturers using them in Britain, the Continent and further afield, to obtain greater protection from risks through hedging. Although not universally popular, speculation in futures worked to level out prices on each market and between markets. ${ }^{7}$

\section{Organisation, MEMBERShip AND RULES}

The London and Liverpool commodities markets started as informal gatherings of merchants interested in particular commodities and subsequently transformed themselves into formal associations. Thus the Baltic Exchange, an important venue for international dealings in commodities such as grain, tallow and linseed, began life as one of the London coffee houses. It remained as an unincorporated association, although a Baltic Company Ltd was incorporated in 1857 under the Joint Stock Companies Act 1856 to buy new premises where dealings could take place. Its rules related to little other than membership. From the second part of the nineteenth century the organisational framework for commodities trading was provided by the relevant trade associations and by the bodies they spawned like the London Produce Clearing House. Other trade associations were responsible for other markets. These took corporate form from the 1880s. This was both the fashion of the times but also had distinct advantages when the common law of associations was underdeveloped. Incorporation offered a pattern of organisation both internally (e.g. control over membership) and externally (e.g. the ownership of property; the ability to sue). ${ }^{8}$

Conditions for membership formed an important component of the rules of these associations. The rules and regulations drawn up in 1823 for "The Baltic

\footnotetext{
${ }^{6}$ J.G. Smith, Organised Produce Markets (London: Longmans, Green and co , 1922). See also S.S. Hoebner, 'The Functions of Produce Exchanges', Annals of the Amer Acad of Pol and Soc Sci, [hereafter Annals] Vol. 38, No.2, Sept. 1911, 319.

7 The main markets examined are, in broad outline:

Commodity Trade Association

(a) London

grain

Trade Association

London Corn Trade Association

sugar Sugar Association of London

coffee

rubber

vegetable oils

copper, tin, lead, zinc

Coffee Trade Association

Rubber Association of London

[Oil Brokers' Association]

London Metal Exchange

Venue

Baltic Exchange

London Commercial Sale

Rooms/ Plantation House/

London Commodity Exchange as above as above

Baltic Exchange own premises

\section{Liverpool Corn Trade Association own premises Liverpool Cotton [Brokers] Association own premises}

However, we will encounter markets in other commodities like tallow and spices.
${ }^{8}$ See Liverpool Corn Trade Association Ltd. v Monks (HM Inspector of Taxes) [1926] 2 KB 110.
} 
Coffee-House' limited membership to three hundred with no more than six members from the Stock Exchange (associated, it was said, with undue speculation). New members were to be admitted only on the recommendation of six other members and approved by the committee. ${ }^{9}$ Prospective members had to be proposed and seconded by members to whom they were personally known, their names had to be publicised to other members and then there was a ballot by the committee. Once elected, however, there was nothing in the way of formal rules for behaviour. Informal conventions operated. A member's word, it was said on the Baltic, was his bond but this in a narrow sense meant simply that as soon as members made an agreement verbally they could not resile from it. ${ }^{10}$ One had to look to the trade associations such as the London Corn Trade Association for any formal rules governing the behaviour of those trading on the Baltic.

Expulsion was the other side of the coin to admission. While typically there was a wide discretion in the rules as to admission, decisions on expulsion were more closely confined. Insolvency became an almost automatic ground for suspension or expulsion. Unable by law to trade in the ordinary way, the insolvent was ipso facto unable to be a member of a market. In addition to insolvency itself, organised markets soon recognised that they should act preventively in relation to those threatened with insolvency. That was because the market would be disrupted if insolvency should occur and a member was unable to settle accounts with others. Thus, the rules of the Liverpool Cotton Brokers' Association provided for automatic expulsion for insolvency but also that the committee should investigate reports of bad debts of a member. An adverse report could be misconduct rendering it undesirable for him to continue as a member. ${ }^{11}$ The procedures were summary, with the decision being made by a majority of at least two-thirds of the committee in London at the time. There was to be no appeal.

With time, trade associations operating markets in particular commodities developed rules - rules as to the contracts to be used, how transactions were to be effected, the operation of clearing and settlement systems, and arbitration. It was natural that breach of these, at least in extreme cases, should become an additional basis for expulsion. In its Constitution, Laws and Usages of 1881 the Liverpool Cotton Brokers' Association addressed expulsion under the heading 'Responsibility, Insolvency and Misconduct' and provided for a member 'persistently guilty of infringement of the Rules or of such misconduct as shall... render it undesirable that he should continue to be a Member.'12 Thirty years later the Liverpool cotton rules were still as open textured - dishonourable or disreputable conduct in a member's dealings - although the range of sanctions had been expanded so that a reprimand, fine and suspension were added to the threat

\footnotetext{
${ }^{9}$ Baltic Rules 1823, rr.2-3. See also rr.4-5 (subscriptions), r.7 (visitors), rr.9-10 (meetings). The 1823 rules are set out in J.A. Findlay, Baltic Exchange (London: Witherley \& Co, 1927) 14-16.

10 W.C. Mackenzie, “The Baltic": Its History and Work', (1900) 12 The Windsor Magazine, 559, 562. Extraordinarily, the first code for behaviour was introduced in 1983: The Baltic Code 2003. Guidance for Brokers in the Baltic Exchange Market (London, 2003) 4.

$11 \mathrm{rr} .31,33$.

$12 \mathrm{rr} .31-3$
} 
of expulsion. Other trade associations also adopted disciplinary action short of expulsion. The relevant clearing-house might restrict a party's trading either by limiting the number of contracts it could register, or refusing it the right to register contracts altogether.

Prompted by an agreement with the Bremen Cotton Association, the Liverpool Cotton Association spelt out the meaning of dishonourable or disreputable conduct in 1909 to include wilful and intentional non-fulfilment of contract, or fraudulent and flagrant breach of contract; frivolous repudiation of contract; and refusal to refer any question in dispute to arbitration or to abide by an arbitration or appeal award, unless arbitration was specifically excluded by the contract. ${ }^{13}$ When these arrangements were considered in the Chancery Division in 1911 the judgment reflected the prevailing judicial attitude of non-interference with the actions of trade associations regarding members' behaviour, except in the most extreme circumstances. ${ }^{14}$ Non-interference with the disciplinary decision there was based on principles of company law, an incorporated association's rights to exclude a member of the company. What about couching the legal argument in other terms? In 1900 a member of the Tea Clearing House was expelled for breach of the association's price fixing rule. It argued that it had been denied natural justice because inter alia it had not been given the opportunity of being heard in its defence. ${ }^{15}$ The case went off on a technicality, although if natural justice had been addressed the authorities suggested that a trade association like the Tea Clearing House would have had to give the member notice of the grounds for disciplinary action and accord him a hearing. ${ }^{16}$ Other than natural justice, and perhaps error of jurisdiction, there was in large part an absence of judicial control. Members had to prove malice, improper motives or bias on the part of the decision-makers, all very high hurdles. ${ }^{17}$

In the interwar period the standards expected on markets became more formalised. Some commodity markets' disciplinary action no longer turned on vague standards like dishonourable or disreputable conduct. By 1922 the Liverpool Corn Trade Association had a list of causes rendering a member liable to expulsion, suspension or payment of a fine. Perhaps the trend of the law, in particular a tightening of procedural requirements for expulsion, had an influence in this concretisation of the grounds for disciplinary action. ${ }^{18}$ It might also have been, especially in Liverpool markets, that there was some permeation of United

13 Merrifield, Ziegler \& Co v Liverpool Cotton Association Ltd. (1911) 105 LT 97.

14 ibid 104.

15 Chamberlain's Wharf Ltd v Smith [1900] 2 Ch 605.

16 e.g. Wood v Wood (1874) LR 9 Ex 190 (mutual insurance society); Labouchere v Earl of Wharncliffe (1879)

13 Ch D 346 (Beefsteak Club). See W.A. Robson, Justice and Administrative Law (London: Macmillan, 1928) 229.

17 Weinberger v Inglis [1919] AC 606, 616-7, 621, 624-6, 631. See also Cassel v Inglis [1916] 2 Ch 211; D. Lloyd, 'The Disciplinary Powers of Professional Bodies' (1950) 13 MLR 281, 292-4; Z. Chafee, 'The Internal Affairs of Associations Not for Profit' 43 Harv LR 993, 1005-6. See also J. Lurie, 'Commodities Exchange as Self-Regulating Organisations in the Late $19^{\text {th }}$ Century: Some Perimeters in the History of American Administrative Law' (1975) 28 Rutgers LR 1107, 1138-9.

18 e.g. Young v Ladies' Imperial Club [1920] 2 KB 523. See S. Stoljar, Groups and Entities (Canberra: Australian National University Press, 1973) 50. 
States practice where the rules for commodity exchanges spelt out a range of specific and more general prohibitions on behaviour.

\section{BROKERS, RULES AND THIRD PARTIES}

The emergence of organised commodity markets was accompanied by the growth of a class of specialised brokers. The law insisted on some rigid distinctions. One such distinction was between brokers and factors, the former middlemen making contracts between buyer and seller, the latter always entrusted with the possession of the property they dealt with. ${ }^{19}$ Another distinction was in the role of the broker, that he was strictly 'a middleman, an intermediate negotiator between other parties' and was not authorised to buy or sell in his own name. ${ }^{20} \mathrm{~A}$ modern economic historian has deprecated the 'verbose attempts' of nineteenth century lawyers to make such firm distinctions about brokers where they seldom existed and noted the 'entrepreneur's silent determination to pursue profit wherever it beckoned'. ${ }^{21}$ Certainly some commodities brokers trading in markets on their own account became more remunerative than relying on the brokerage earned by acting for others. ${ }^{22}$

The law provided a backdrop to brokers' this commercial activity. One aspect concerned the rights and liabilities of brokers vis-à-vis other brokers (and these other brokers' principals); another aspect, the relationship between brokers and their clients. Market practice offered the starting point for the first. Until the second part of the nineteenth century, when commodity markets began adopting formal rules, the law relied largely on trade usage to define the rights and liabilities of brokers between themselves. Trade usage was the course of dealing in particular markets which had attained such notoriety that brokers could be said to be bound by it if it was reasonable and not inconsistent with any contract. It was invoked in relation to various commodity markets to define a broker's rights and duties..$^{23}$ Once market rules were formalised these became binding on brokers as members of the trade association which drew them up. We have seen that members of a trade association could be sanctioned for non-compliance with the rules. To reinforce the point the practice of the London Produce Clearing House was to have brokers sign the regulations, 'thereby engaging himself to abide by all these

19 e.g. J.W. Smith, A Compendium on Mercantile Law (London: Stevens, 6th ed, 1859) 118.

20 Joseph Story, Commentaries on the Law of Agency as a branch of Commercial and Maritime Jurisprudence (London: Little Brown, 1839) 24-5.

21 S. Chapman, Merchant Enterprises in Britain (Cambridge: Cambridge University Press, 1992) 77.

22 C.H. Woodhouse, The Woodhouses, Drakes and Careys of Mincing Lane (London: self published, 1977), 33.

23 e.g. Johnston v Usborne (1841) 11 Ad \& E 550; 113 ER 524 (grain trade in London); Greaves v Legg (1856)

11 Ex 642, 156 ER 988 (Liverpool trade, wool from Odessa); Inman v Clare (1858) 5 Jur (NS) 89, 70 ER

629 (Liverpool cotton trade); Imperial Bank v London and St Katharine Docks Co (1877) LR 5 Ch D 195 (London dry goods market); Bacmeister v Fenton, Levy \& Co (1883) Cab \& E 121 (rice trade); Pike Sons \& Co v Ongley (1887) 18 QBD 708 (hop trade). 
rules'. ${ }^{24}$ Signature made unequivocal the commitment of the member to abide by the rules and the authority the clearing house had over him. ${ }^{25}$

It became the standard practice for brokers on commodity markets to make contracts in their own name. There was evidence of that in the coffee trade in the early nineteenth century, ${ }^{26}$ the London grain market of the early 1840s, at least with foreign principals, ${ }^{27}$ and Pulling asserted it to be accepted 'in the West India and other trades'. ${ }^{28}$ In the absence of formal rules, his conclusion that 'in such cases, the broker is personally answerable for its fulfilment...' could have only been as a matter of trade usage on those markets since the common law lacked a bright line rule. ${ }^{29}$ Under the common law doctrine of undisclosed principal, even if the broker contracted in its own name, without revealing the existence of a principal, the principal could subsequently claim the benefits of the transaction for itself. The eighteenth and early nineteenth century law to this effect was applied by the House of Lords to the Liverpool cotton market in the leading case, Cooke \& Sons $\mathrm{v}$ Eshelby. ${ }^{30}$ That involved the sale by Liversay \& Co, brokers, for an undisclosed principal, N.C. Maximos, now bankrupt. Eshelby, the trustee in bankruptcy, sued the buyers, Cooke \& Sons, who contended that they could setoff against the price of the cotton a debt the brokers owed them. The House of Lords held there was no right of set-off. In an interrogatory Cooke \& Sons in effect admitted that they dealt with the brokers knowing that they could be acting as agents or on their own account. The law lords reasoned that given that this was the practice on the Liverpool cotton market, sale by a broker in its own name to a person knowing the practice was no assurance it was selling on its own account. If a person desired to deal with the broker as principal, in order to acquire a right of set-off, he should make inquiries as to the capacity in which the broker was acting. The Lord Chancellor, Lord Halsbury, was quite unsympathetic to the difficulties posed for brokers by the doctrine of undisclosed principal: We must not alter the law to suit the views or the convenience of the Liverpool Cotton Market'. ${ }^{31}$

Uncertainly of this nature was far from satisfactory for the functioning of markets. Those transacting on a market needed to know at the time against whom claims might be levelled. Certainty was undermined if an undisclosed principal

\footnotetext{
${ }^{24}$ Regulations for Coffee Future Delivery Business, May 1888, Preliminary Regulations for the Admission of Brokers, r.10; Preliminary Regulations for the Admission of Brokers and Agents authorised to deal with the London Produce Clearing House Ltd., in Sugar Business for Future Delivery, February 1889, r.12, GH, MS 3641/1, 118-9, 121.

25 J. Baer \& G. Woodruff, Commodity Exchanges (New York: Harper, 1929) 241.

26 Waring v Favenck (1807) 1 Camp 85, 170 ER 886; Kymer v Sunvercropp (1807) 1 Camp 109, 180; 170 ER 894, 921.

27 Johnston v Usborne (1841) 11 Ad \& E 550; 113 ER 524.

28 A. Pulling, Laws, Customs, Usages and Regulations of the City and Port of London (London: Stevens, 2nd ed, 1844) 423n.

${ }^{29}$ Fairlie v Fenton (1870) LR 5 Ex 169 (Liverpool cotton broker); Southwell v Bowditch (1876) LR 1 CPD 374 (a contract made by a colonial broker for export of anthracene, used for dying).

30 (1887) LR 12 App Cas 271. See also Calder v Dobell (1871) LR 6 CP 486, an earlier case on Liverpool cotton.

31 ibid 281. Lord Blackburn was one of many critics of the doctrine of undisclosed principal, although the objection was not to the commercial implications: Armstrong v Stokes (1872) LR 7 AB 598, 610; see also Frederick Pollock's critical note of Cooke \& Sons v Eshelby at (1887) 3 LQR 358, 359.
} 
could later emerge to assume the transaction as its own. Contract offered a solution. Bought and sold notes in commodity markets had a clause added that the contract of which they were a note was made between the brokers themselves and not with any other person, whether disclosed or not, on whose instructions or for whose benefit it was entered. ${ }^{32}$ Trade associations adopted a rule that when dealing either themselves or for clients members could deal in their own name. C.W. Smith, a broker in Liverpool, recalled in evidence to the Royal Commission on Agriculture:

[T] here was a celebrated case called Cooke v. Eshelby ... I brought it before our Association, and I told them that if the thing was going on, no man dare trade under those systems. The consequence was that a committee was formed, and a new contract was made out which makes every man under that contract himself liable, do you see, as his own principal under every contract, so that there was no going behind anybody and therefore, under the settlement system every contract is wrung out compulsorily. 33

Such a rule might add that members were then personally liable on any contract and no rights or liabilities accrued to a principal, except against his own broker. ${ }^{34}$ The London Produce Clearing House echoed this in its rules, in some versions also conferring a discretion on itself to decide whether to permit a hitherto unidentified client from having its name substituted and, if so, subject to what conditions. ${ }^{35}$ The authorities suggested that such a clear expression would assure privity of contract between the brokers themselves and preclude parol evidence about any undisclosed principal. ${ }^{36}$ As well as excluding the doctrine of undisclosed principal such rules meant the broker was liable if its principal failed to take delivery and to pay itself any margins in relation to a futures contract.

The relationship of brokers with their clients - the second aspect to be considered - fell, in part, within the purview of agency law, although it raised other issues such as the binding quality of market rules as regards clients. Nineteenth century agency law established that brokers, as agents, were subject to a number of duties: to act within the scope of their authority, to execute market orders with proper care, skill and diligence, and to avoid conflicts of interest and secret profits. For a period these duties from the general law were overlaid in the City of London by special regulations for brokers. ${ }^{37}$ The legislation dated from the early eighteenth century, but the mayor and aldermen of the City remade the rules and regulations

\footnotetext{
32 H.D. Bateson, 'Forms of Mercantile Contracts' (1895) 11 LQR 266, 268-9 and 271-2.

33 Royal Commission on Agriculture, C.7400, 1894, v.16, pt.2, 51.

34 e.g. Beetroot Sugar Association, Rules and Regulations, $8^{\text {th }}$ ed, 1904, rr. 44, 215. See a case at the end of our period, concerning the cocoa and sugar futures market in London: E. Bailey \& Co. Ltd vBalbolm Securities Ltd [1973] 2 Lloyd's Rep 404, 408.

35 e.g. London Produce Clearing House, Coffee Future Delivery Business, May 1888, r.9.

${ }^{36}$ See S.J. Stoljar, The Law of Agency: its history and present principles (London: Sweet and Maxwell, 1961) 2202.

37 e.g. J.A. Russell, A Treatise on the Laws relating to Factors and Brokers (London: H. Sweet, 1844) 344-8; J.A. Russell, A Treatise on Mercantile Agency (London: H. Sweet, $2^{\text {nd }}$ ed, 1873) 6-7.
} 
in 1818. Under these brokers had to obtain the permission of the City authorities before acting as such. Admission as a broker meant producing a certificate of competence and knowledge and then acting in accordance with certain standards. ${ }^{38}$ Thus a broker was forbidden from dealing in his own name, had to enter every bargain into a broker's book and could not take or receive double brokerage (e.g. from both buyer and seller). Agitation that they were a restraint of trade and an impediment to business led to their repeal in large part in 1870.39

As with any body of law, that governing brokers' duties to their clients did not always produce clear-cut answers. There was uncertainty about the scope of the City's regulations, and in particular to what category of brokers they applied. Moreover, the regulations were flouted in practice. ${ }^{40}$ On the Baltic Exchange, and other London markets, brokers acted both as middlemen and on their own account. Some time after the repeal of the regulations the Baltic Exchange introduced a 'Broker's Letter', whereby broker members undertook not to deal directly or indirectly on the Exchange on their own account. However, members could do so on other markets so long as they disclosed the name of any principal if they transacted business with another member of the Baltic. By 1931192 members had signed a broker's letter, including 39 grain brokers and 15 oil brokers. ${ }^{41}$

As for the general law, Christoforides v Terry ${ }^{42}$ is a useful illustration of the difficulties. Christoforides involved speculative dealings on the Liverpool and New York cotton markets. A client had been caught out by a fall in cotton futures. Since he was unable to make good the call for margins, the broker had closed out his contracts in the market and now demanded an indemnity for the losses incurred. By the time the case reached the House of Lords the broker's right to close out had been accepted. ${ }^{43}$ However, the customer now contended that the broker was not entitled to his indemnity since he had been in breach of his duties to avoid a conflict of interest. On the day the broker closed out two of the customer's contracts he had simultaneously repurchased the same quantities of cotton from the same brokers at the same price. It was said that this breached his fiduciary duty not to put himself in a position where his interest conflicted with that of the client. The analogy was drawn with brokers buying their client's securities. The House of Lords did not see how they could disturb the finding of the trial judge that the closing out transactions were bona fide and not a sham, and thus held that the broker's purchases could not vitiate them. But it was obvious

\footnotetext{
386 Anne, c.16. See also 57 Geo 3, c.60. See 'Rules, Orders and Regulations' in Appendix No. III, Russell, A Treatise on the Laws relating to Factors and Brokers, ibid 344-8. See also n 28 above, 418-24.

${ }^{39}$ London Brokers Relief Act 1870, 33 \& 34 Vict, c.60. See J.A. Findlay, The Baltic Exchange (London: Witherley \& Co., 1927) 46.

40 e.g. Exp. Dyster (1816) 1 Mer 155, 169-70; 35 ER 632, 637.

${ }^{41}$ H. Barty-King, The Baltic Exchange (London: Hutchinson, 1977) 342. The oil brokers were dealers in vegetable oil.

42 [1924] AC 566.

43 This issue was a factual one as to whether the contract allowed this provided sufficient security was available: see Sankey J's judgment in Cases on Appeal to House of Lords, vol.702, 1924, 67-8 (80-2) (Lincoln's Inn).
} 
that not all fully understood the workings of futures markets. Most notably Viscount Finlay was taken in by the argument that the purchases were a resale to the broker, emphatically not the case with futures transactions which under the contract were not referable to particular cotton. ${ }^{44}$

Brokers, then, were under certain duties to the client. What of the broker's rights against the client? Christoforides v Terry began as a claim for indemnity, perhaps the most important common law right which an agent had against the client. At the outset of any claim against the client, however, it was necessary to determine whether the broker was, in fact, an agent; brokers might be acting as principal for their own account. In the commodity markets the capacity in which brokers were acting was usually evident from the bought or sold notes they gave clients. 'Sold for $\mathrm{AB}$ ', 'bought for $\mathrm{CD}$ ' or 'sold from $\mathrm{AB}$ to $\mathrm{CD}$ ' all indicated agency. But, as the standard treatises pointed out, the form 'sold to you by me' meant the broker was assuming the obligation of principal. 45 In practice the rights which a broker might wish to assert against his client derived in large part from the rules and practices of the market. As we have seen brokers themselves were bound by these rules and practices. To what extent were clients? The law struggled with, and never satisfactorily resolved, the issue of the relationship between third parties and markets. On the surface contract law was of no assistance, especially when the doctrine of privity of contract became entrenched. Not being a party to the rules of a market, clients were not bound by them nor were they in a contractual relationship with the market or related institutions like the clearinghouse. Their contact was with their broker, acting on their behalf.

Initially weight was put on agency law to address the problem of the third party. It was established early in relation to a stock exchange that a client employing a broker impliedly gave him authority to act in accordance with its rules although the client himself was ignorant of them. ${ }^{46}$ This use of agency law was subsequently extended to other markets and beyond market rules to customs and practices. 'A person who deals in a particular market must be taken to deal according to the custom of that market...' 47 The matter came to a head in a case involving a transaction on the Baltic Exchange. In Robinson $\mathrm{v}$ Mollett+8 Robinson was a Liverpool merchant. As on several previous occasions, he had instructed brokers, Mollett \& Co, to buy tallow in this case in April for June delivery. As we have seen, tallow as an object of speculation on the Baltic and subject to significant fluctuations in price. There can be little doubt that Robinson was speculating, a point which Mollett's counsel, J.P. Benjamin QC made, but without

${ }^{44} \mathrm{n} 42$ above, 573. And several others seemed to be struggling. That formidable commercial lawyer, J.A. Hamilton (Lord Sumner), saw the realities of futures markets most clearly (ibid 78-9).

${ }^{45}$ C. Blackburn, A Treatise on the Effect of the Contract of Sale (London: W. Benning, 1845) 89. See also J.D. Benjamin, Benjamin's Treatise on the Law of Sale of Personal Property (London: H. Sweet, 4th ed, 1888) 252.

46 Sutton v Tatham (1839) 10 Ad \& E 27; 113 ER 11. See J.H. Balfour Browne, The Law of Usages and Customs (London: Stevens \& Haynes, 1875) 91.

47 Bayliffe v Butterworth (1847) Exch 425, 429.

48 (1875) LR 7, HL 802. See also Bostock v Jardine (1865) 3 H \& C 700; 159 ER 707; Cropper v Cook (1868) LR 3 CP 194, 200. See another case in the same market: Greaves v Legg (1854) 11 Ex 642, affd. 156 ER 988; 2 H \& N 210 
effect. ${ }^{49} \mathrm{He}$ was sent bought notes in the usual form, We have this day bought of ... for your account...'. The practice of the market was that tallow brokers could buy tallow for various persons in their own name, then on settlement day balance orders between themselves, allotting tallow to those who wanted delivery and otherwise paying or claiming price differences. ${ }^{50}$ The price of tallow fell after this particular transaction and Robinson refused to accept delivery or to pay in accordance with the contract. The brokers laid the matter before the Committee of the Baltic which said that they had acted 'quite straightforwardly in the matter and according to the rules and customs of the trade'. ${ }^{51}$ The defendant still refused delivery or to pay, and on being sued his lawyer now sought legal justification for his action with the argument that he could not be bound by a market practice of which he was unaware.

The lower courts were divided. ${ }^{52}$ In the House of Lords, however, formalism won the day. The submissions of J.P. Benjamin QC for the brokers, which began by referring to the undoubted 'usefulness' of the Baltic's practice, fell on deaf ears. ${ }^{53}$ Story's view in Agency ${ }^{54}$ was cited by counsel for the purchaser, that a broker is a mere negotiator between other parties. In a judgment with which other members of the House of Lords agreed, Lord Chelmsford held that what market custom and practice did here was to reverse completely a broker's character 'who is an agent to buy for his employer, into that of a principal to sell for him' which the purchaser, who was ignorant of it, could not be taken to have authorized. ${ }^{5}$ Neither the bought notes nor other facts of the case gave any indication to third parties of the existence of a market practice 'of such a peculiar character...' that it could be binding on them, even if it could regulate the dealing of brokers between themselves. 56

The principle of Robinson $\mathrm{v}$ Mollett remained; in a leading case regarding the commodity markets the United States Supreme Court described it as 'incontrovertible'. ${ }^{57}$ But it was confined to situations where a person employed as broker executed his commission by selling his own goods to the client. ${ }^{58}$ In general clients were bound by market rules and practices. Those who engaged brokers to transact their business on a market did so on terms that it would be conducted in accordance with the rules. ${ }^{59}$ Contract was used to make that plain. Brokers' bought and sold notes were expressed such that any contract was made

\footnotetext{
49 Cases on Appeal to the House of Lords, v.302, 1875, 248-53 (52-7), which sets out some of the correspondence (Lincoln's Inn ).

50 This was also standard practice on the London and New York Stock exchanges: Clews v Jamieson 182 US 461, 487 (1901).

51 Cases on Appeal to the House of Lords, n 49 above, 268-9 (72-3).

52 (1870) 5 CP 646; (1872) 7 CP 84.

53 (1875) LR 7, HL n 48 above, 807.

54 n 20 above.

55 (1875) LR 7, HL n 48 above, 836.

56 ibid 835, 838.

${ }^{57}$ Irwin $\mathrm{v}$ Williar 110 US 499, 515 (1884).

58 e.g. Exp Rogers (1886) 15 Ch 207, 210, 214.

59 Weinberger v Inglis [1919] AC 606, 619 per Lord Buckmaster.
} 
subject to the rules and bye-laws of the relevant trade association. ${ }^{60}$ Once trade associations began issuing standard form contracts these may set out key rules in the small print or incorporated them by reference through a term of the contract.

\section{ARRIVALS AND FUTURES MARKETS}

What firstly we see as the basis of futures contracts is the emergence of arrivals markets in commodities from abroad. From the early nineteenth century the courts were handling disputes about commodities like tallow, hemp and palm oil sold under contracts 'on arrival' or 'to arrive' in a port such as London. In 1834 a London merchant involved in foreign grain sales gave evidence of future sales of grain to be delivered, and of 'time sales', where grain was deliverable at the end of a month, say, and if not delivered 'whatever the difference of price is in the market of course it must be made good'. ${ }^{61}$ Cotton was also sold to arrive. An arrivals contract would specify the commodity, its quantity and perhaps quality, as well as the departure date and port (e.g. St Petersburg or Crondstadt in June or July). The ship might be named (e.g. per the Mansfield) or the contract might provide for the ship's name was to be declared later (e.g. 'ship's name declared as soon as known'). Because of the vagaries of sailing times the contract would not specify a date of arrival although it might provide that it should not exceed a given date. ${ }^{62}$ Under the contract buyers might have the option of directing the ships to ports of their choice, including those in continental Europe. ${ }^{63}$ Arrival contracts meant the buyer knew where the commodity was coming from and what ship was carrying it, if not initially, at least after shipment.

Dealings might occur in arrivals contracts before the commodity arrived as it was sold on to others. Thus there was a secondary market in Liverpool cotton contracts 'to arrive' and trading was especially active in Liverpool during the speculation of 1857.64 The recommended standard form of contract 'to arrive' settled in the 1860s by the Liverpool Cotton Brokers Association identified the origins of the cotton as coming from a particular port on a particular ship. ${ }^{65}$ In other contracts the ship might not be named until after the contract was made, but it seems to have been a practice, and was certainly later a rule of the association,

\footnotetext{
${ }^{60}$ n 32 above, 268-9.

${ }^{61}$ Report of Select Committee on Sale of Corn, Parliamentary Papers, 1834, 517, VII, 1, 79-80.

62 Hawes v Humble (1809) 2 Camp 327n; 170 ER 1172 (tallow); Boyd v Siffein (1809) 2 Camp 326; 170 ER 1172 (Riga Rhine hemp); Lovatt v Hamilton (1839) 5 M \& W 639; 151 ER 271 (African palm oil to arrive Liverpool per the Mansfield); Gorrisen v Perrin (1857) 2 CBNS 681; 27 LJCP 29; 140 ER 583 (bales of gambier from Singapore 'expected to arrive' in London per two named ships).

63 e.g. Ex p Halliday. Re Hall \& Jones (1865) 2 De GJ \& S 312; 46 ER 396 (sale of cargo of rice ex 'Southern Rights').

${ }^{64}$ S. Dumbell, 'The Origin of Cotton Futures' (1927) 1 Econ.Hist 259, 260.

65 The contract is set out in two brilliant articles by A.W.B. Simpson, from which I have learnt much: 'Contracts for Cotton to Arrive: The Case of the Two Ships Peerless' (1989) 11 Cardozo LR 287, 312 [hereafter 'Two Ships Peerless']; 'The Origins of Futures Trading in the Liverpool Cotton Market', in P. Cane \& J. Stapleton, Essays for Patrick Atiyah (Oxford: Clarendon Press, 1991) 185-6 [hereafter 'Futures Trading']. See also the contract in Neill v Whitworth (1865) 18 CB (NS) 433, 144 ER 513.
} 
for such a declaration be made sometime after the contract. ${ }^{66}$ In the 1860 s, reflecting the greater predictability of voyage times, arrival contracts began to be used which named a one or two month period when the cotton would arrive. More importantly, the form of contract used might not provide for delivery of specific cotton tied to a particular ship, named or to be named, but of cotton of a particular description. ${ }^{67}$ This clearly presages the futures contracts of a decade later.

There was no difficulty for these arrival contracts from English sales law. From early in the nineteenth century the courts upheld contracts for the sale of goods to be delivered later. Thus it was held that the sale of a growing crop of hops did not constitute the old offence of forestalling. ${ }^{68}$ Brewers had used such contracts for future delivery for many years to secure their supplies of malt. The principle applied as well to commodities to be made by processing. ${ }^{69}$ So the validity of a contract to sell what was to be delivered in future was settled law. Subsequently, the courts upheld contracts when the seller did not have the commodity at the time of sale but was to acquire it. and deliver it after making the contract. ${ }^{70}$

A second development germane to the emergence of futures contracts was the growth of speculation in commodities markets. There had always been speculation in the physical markets, for example, the purchase of grain and storing it in expectation of a rise in price. While this type of speculation continued there was also speculation in the arrivals markets. Speculation in tallow in the first part of the nineteenth century on the Baltic Exchange included 'delivery' transactions, said by one commentator to be 'the description of contract that would allow of a rise or fall in price, it usually embracing a period of two or three months forward.... ${ }^{71}$ With cotton, speculation was most likely with spot transactions because its variability in quality meant there were risks in buying it without the opportunity to inspect. Speculation in relation to arrival contracts in cotton became common in the $1850 \mathrm{~s}$ as a result of the improvement in communications. ${ }^{72}$ It was the attraction of enormous profits which stimulated speculation in arrival contracts during the American Civil War. Specified amounts of particular types of cotton were re-sold, sometimes many times, so that on settlement documents and payment had to pass along the chain. ${ }^{73}$ Many of those

${ }^{66}$ See rule 2 set out in Thorburn $\mathrm{v}$ Barnes (1867) 16 LT (NS) 10, 12.

${ }^{67}$ e.g. Williams vReynolds (1865) 12 LT (NS) 729, 729.

${ }^{68}$ Bristow $\mathrm{v}$ Waddington (1806) 2 Bos \& Pul (NR) 355; 127 ER 664; Waddington $\mathrm{v}$ Bristow (1801) 2 Bos \& Pul 451, 126 ER 1379. The plaintiff in these actions had come unstuck shortly before in a criminal prosecution brought by hops factors allied to London brewers, who resented his advancing credit to growers for their future crops, thus breaking their own hold: D Hay, 'The State and the Market in 1800: Lord Kenyon and Mr Waddington’ Past and Present, No.162, February 1999, 117, 123.

${ }^{69}$ e.g. Wilks v Atkinson (1815) 6 Taunt 10, 11-12; 128 ER 935, 935-6.

70 Hibblewbite v McMorine (1839) $5 \mathrm{M} \& \mathrm{~W}$ 462; 151 ER 195; Borrowman, Pbillips \& Co v Free \& Hollis (1878) LR 4 QBD 500, 502, per Bramwell LJ.

71 Anon, The City; or, the Physiology of London Business (London: Groombridge \& Sons, 1852) 138.

${ }_{72}$ J.H. Todd, The Marketing of Cotton (London: Pitman and Sons, 1934) 66.

73 Simpson, Futures Trading, n 65 above, 190-4, 202 writes of the assignment of contracts but this overlooks cases like Williams vReynolds (1865) 12 LT (NS) 728. 
engaged in buying and selling the cotton had no interest in taking delivery and simply hoped to profit on reselling it. Short-selling was also in evidence. ${ }^{74}$

On the back of arrival contracts and speculation emerged futures, where trading occurred without reference to identifiable shipments of a commodity but by description and according to grade. There is a period in the 1860s and $1870 \mathrm{~s}$ when it was occurring informally, by use of forms of arrivals contracts drawn up by individual traders, with a month or months specified within which the commodity would arrive. Thus the form of contract in Williams $\mathrm{v}$ Reynolds. ${ }^{75}$ As Blackburn J noted perceptively in that case, the contract 'was not for the delivery of specific cotton, but of cotton of a particular description'. ${ }^{76}$ This became the hallmark of the futures contract.

The Chicago Board of Trade seems to have been the first to formalise futures trading in 1865. ${ }^{77}$ Others quickly followed. The Liverpool Cotton Exchange began futures trading in the $1870 \mathrm{~s} .{ }^{78}$ For grain the Liverpool Corn Trade Association drew up its first futures contract in 1883. ${ }^{79}$ Standardised contracts were not a necessary condition for futures dealing but certainly facilitated it. Importantly the association laid down standard grades as well as the time and method of delivery (if delivery was necessary). ${ }^{80}$ Identical terms in contracts meant that the only variable needing negotiation was price. Fungibility also enabled those dealing on a market to close out a position without difficulty by entering an offsetting transaction. One example of a standard futures contract suffices. The 1903 Liverpool futures contract for wheat incorporated, at the outset, the rules of the Liverpool Corn Trade Association. ('We have this day Bought from/sold to [ ] on the terms of the Printed Rules of...'). ${ }^{81}$ The price per $100 \mathrm{lbs}$ was to be inserted, as was the quality and month of delivery. Unlike the earlier 'to arrive' contracts, and contemporaneous 'shipment and delivery contracts', the only specification as to the origin of the wheat was in relation to its grade.

74 e.g. Morgan v Gath (1865) 13 LT (NS) 96.

75 (1865) 12 LT(NS) 728.

76 ibid 730 .

77 J.W. Markham, The History of Commodity Futures Trading and its Regulation (New York: Praeger, 1987) 4. Futures trading is said to have occurred in previous centuries, e.g. in grain and herring in Amsterdam and on the Rice Exchange in Osaka: C. Wilson, Anglo-Dutch Commerce and Finance in the Eighteenth Century (Cambridge: The University Press, 1941) 81; M.D. West, 'Private Ordering at the World's First Futures Exchange' (2000) 98 Mich.LR 2574.

${ }_{78}$ Simpson, Futures Trading, n 65 above, $196 \mathrm{ff}$.

${ }^{79}$ Liverpool Corn Trade Association, Liverpool Corn Trade Association 1853-1953 (Liverpool, 1953), 12-25; H. Working \& S. Hoos, 'Wheat Futures Prices and Trading at Liverpool since 1886' (1938) XV (3) Wheat Studies of the Food Research Institute, Stanford University, California 121; G.J.S. Broomhall \& J.H. Hubback, Corn Trade Memories (Liverpool: Northern Publishing Co, 1930) 1-13.

${ }^{80}$ Settlement in grades rather than the standard grade might be permitted, with price differences to compensate for the variation.

81 Set out, along with the 1934 version, in Working \& Hoos, n 79 above, Appendix Notes. cf. the much shorter United States grain future contract from the New York Produce Exchange: A.C. Stevens, 'Futures in the Wheat Market' (1887) 2 QJ Econ 37, 38. 


\title{
CLEARING AND SETTLEMENT
}

\author{
'... Denry was not satisfied. He had a secret woe, due to the facts that he was gradually ceasing to be a card, \\ and that he was not multiplying his capital by two every six months. He did not understand the money \\ market, nor the stock market, nor even the financial article in the Signal; but he regarded himself as a \\ financial genius...' 82
}

'Back office' functions like clearing and settlement in markets are even less appreciated or understood than the operation of the markets themselves. Clearing is the process whereby counterparties have their claims and obligations reconciled; settlement then occurs so that the consequent liabilities are extinguished. From the eighteenth century the concepts of clearing and settlement were well developed in banking. The aims were to reduce the administrative burden and the amount of cash banks needed to fulfil their customer's orders. Clearing and settlement become essential with commodity markets of the industrial period as participants would execute many contracts of purchase and sale in a given period. Clearing and settlement in commodity markets went further than bank clearing because not only money accounts but contracts needed to be cleared. The function of clearing houses was to enable those trading in a market to offset (clear) the comparable buy and sell transactions they had entered in a specific period and to pay or receive (settle) the net amounts.

At one level clearing houses operated to handle the documents of title to a commodity being traded in a market. Thus if A sold a commodity to B, who sold to $C$ and so on, it saved time and costs if the documents enabling it to be claimed such as a bill of lading, dock warrant or warehouse receipt passed directly from A to the ultimate buyer. At another level clearing houses became essential when futures transactions began to dominate commodity markets, not least because the volume of trading increased considerably. Most futures transactions were for hedging or speculative purposes. If there were equal sales and purchases, the contract terms were standardised and the description of a commodity and the time of delivery were identical, it was only necessary to settle the difference in prices. Clearing in futures markets might occur prior to the delivery date. That conserved brokers' capital, in particular by enabling them to minimise margin payments.

\section{Commodity Clearing Houses}

The London Produce Clearing House Ltd (LPCH) was incorporated with the object, as stated in the prospectus, 'to place on a secure basis, by a system of deposits, the dealing in produce for future delivery...' ${ }^{83}$ Its first annual report also hinted at the national advantage 'in giving facility of sale with security of contract, and thereby attracting business to London.... ${ }^{84}$ Initially it cleared futures dealings

82 A. Bennett, The Card (London: Methuen \& Co, 1911).

83 Guildhall Library, Prospectuses, No.549.

${ }^{84}$ Kindly provided by David Hardy, chief executive of LCH Clearnet. 
in coffee and sugar. Sugar was especially conducive to futures dealings since, unlike other products like tea and wool, it was easily graded. Later the London Produce Clearing House cleared futures transactions in wheat, maize, pepper, rubber, raw silk, silver, indigo and, for a while at the turn of the twentieth century, tea. It published separate rules for each commodity which, with some exceptions noted below, followed a very similar pattern. ${ }^{85}$ After World War II its rules acquired a general character to cover any commodity where the relevant trade association operating a futures market had an arrangement with it. 86

The London Produce Clearing House followed the model of an independent clearing house, not tied to any particular commodity association. That was also the banking model. Other clearing house for commodities were established by particular markets and in that sense were their captive. Liverpool's clearing house for cotton is illustrative; it also appears to be the first commodity clearing house in Britain. ${ }^{87}$ The clearing houses for the grain trade in both Liverpool, and eventually London, also followed the captive model. The Liverpool Corn Trade Association formed a clearing house in 1883, which was incorporated in 1887. No doubt it was influenced by the system for clearing cotton transactions. Initially it acted as a clearing house for cif contracts. Numerous dealings in these produced a string and the aim of clearing was to facilitate direct settlement between first seller and last buyer. After 1893 the clearing house began clearing futures transactions. ${ }^{88}$

Proposals by the London Corn Trade Association to establish a clearing house in London for registration of cif contracts in grain were considered in the years leading up to World War I. ${ }^{89}$ One factor in the lack of progress was a decidedly unhelpful opinion from $\mathrm{Mr}$ Gore-Browne $\mathrm{KC}$, an expert in company law, whose name is still carried on a leading text on the subject. Gore-Browne was consulted as to the chances of the LCTA obtaining the necessary approval of the Board of Trade and the court, to a change in its articles of association so that it could establish a clearing house. Delivered from Olympian heights, the opinion was both unclear and unhelpful: it was very doubtful whether consent would be obtained, it was a matter of the Board's discretion and it could not be said with any certainty how it could be exercised, but if the association was practically unanimous in favour of change it might be obtained. ${ }^{90}$

85 I have found the following: London Produce Clearing House Ltd, Regulations for Coffee Future Delivery Business, May 1888, British Library; Regulations for Future Delivery Business in Rio Coffee, July 1893, GH, MS 3641/2, 124; Regulations for Future Delivery in Beetroot Sugar 88\%, June 1913, GH, MS 3641/5, 40; Regulations for Future Delivery Business in Cocoa, April 1928, Institute of Commonwealth Studies, University of London. The minutes of the clearing house board record a decision with the first sugar rules to follow the rules for coffee as closely as possible in respect of the registration of contracts, despite the strong objection of one of its leading lights, Caesar Czarnikow: GH, MS 3641/1, 32-4, 35-6, 39-40, 43, 47, 50; 31 May, 6, 27 June, 11, 18 July, 1 Aug 1888.

86 The London Metals Exchange did not use a clearing house but had its own arrangements until well after our period: G.T. Gemmill, Should the London Metal Exchange Use a Clearing House?, City University Business School Commodity Paper No.1 (London, 1979).

87 T. Ellison, The Cotton Trade of Great Britain (London : E. Wilson, 1886) 286; 'The Exchange', Liverpool Review, 11 June 1887, 10; G.L. Rees, Britain's Commodity Markets (London: Paul Elek, 1972) 94-5.

${ }^{88}$ Liverpool Corn Trade Association, $\mathrm{n} 79$ above, 11.

89 e.g. Sub Committee re A Clearing House System, GH, MS 23 174/1, 14 Nov 1905.

${ }^{90}$ Minutes of sub-committees, GH, MS 23 174/3, 24 Feb 1913, 11 Mar 1913. 
Eventually, the project of the London Corn Trade Association for its own clearing house was achieved in 1921. As far as London was concerned futures dealings in grain never prospered, even after they were provided for in 1929. Those transacting grain futures preferred Liverpool. Rather the work of the London clearing house concentrated on clearing documents in string transactions. A clause was inserted in LCTA standard form contracts under which either party could register a contract at the clearing house so that, once registered, it would be subject to the clearing house rules. ${ }^{91}$

While clearing houses for commodities focused on futures transactions it is important not to overlook their contribution, as with these cif string contracts in grain sales, to documentary clearing. Two clearing systems devoted solely to documentary clearing bear closer attention. The first is the Tea Clearing House, an association formed in 1888 by dock companies and warehouse keepers, having dealers carrying on the wholesale trade in tea as subscribers. Among the aims of the association was to facilitate the rapid and efficient lodgement and transmission from a central office of warrants, delivery orders, carding, cording and other orders to the various docks and warehouses. ${ }^{92}$ A sophisticated system developed for documentary clearing for sugar transactions. Formed in 1882 the Beetroot Sugar Association (from 1905 called the Sugar Association of London) devised a system for the use and clearing of filières. Filières represented sugar arrived at port in Britain or on the continent. ${ }^{93}$ Filières passed from hand to hand, successive holders filling in the date, price and time of delivery. Clearing was on a daily basis and the manager of the clearing would, on receipt of tenders, endeavour to liquidate contracts by passing a filière from sellers to buyers until the filière arrived at a buyer who could not pass it on (called in the rules the 'stopper'). ${ }^{94}$ The first seller would then pass the bill of lading or dock or warehouse warrant to the stopper, who paid a price based on its weight and analysis. Upon the manager receiving notice that the documents had passed or liquidation had been otherwise effected, he

shall receive from the middlemen or pay them the difference between their buying and selling prices and receive from or pay the issuer and stopper the difference between their contract prices and the filière price. ${ }^{95}$

\footnotetext{
91 e.g. LCTA, London La Plata Maize Contract. Steamer or Power Vessel. Parcels. Rye Terms. 1938. Conditions and Rules, $₫ 11$.

92 Chamberlain's Wharf Ltd v Smith [1900] 2 Ch 605, 606. See Tea Clearing House, Tea Clearing House Centenary 1888-1988 (London, 1988), for a description of its operation.

93 Thus futures transactions in sugar were different; they were cleared by the London Produce Clearing House.

94 Beetroot Sugar Association, Rules and Regulations, (London, 8th ed, 1904), Clearing Contract, r.317. There is a limited description of the filière system in Encyclopaedia Britannica (11th ed, 1911), 'Clearing'. ${ }^{95}$ r.321.
} 


\section{Processes}

Clearing and settlement by commodities clearing houses was perceived of as a routine administrative process, which only occasionally gave rise to difficulties. That is to underestimate both the skill involved in the matching of transactions and the theoretical underpinning of the task. ${ }^{96}$ The first step in clearing and settlement was the registration of transactions with the clearing house, to record parties' respective claims and liabilities and identify counterparties. This enabled the matching of those who had bought or sold the same commodities for the same delivery dates and allowed intermediate parties to be eliminated. Take the method for registering transactions in grain in Liverpool. Either party could register a contract, if accompanied by the requisite payment. ${ }^{97}$ The clearing house had discretion to refuse registration if in its opinion a transaction was not bona fide or had been entered into for the purpose of evading liability, contrary to good faith. ${ }^{98}$ Following registration, the clearing house recorded a contract on a 'string sheet', the seller appearing as the first seller and the buyer as the last buyer. As either party closed out its side of the contract, further registrations took place. Strings could be extended indefinitely and joined. Those at the end of the string were designated first seller and last buyer. Once intermediate parties had paid the difference in price in favour of their immediate counterparties their obligations ceased.

Registration of a contract at a clearing house was generally conditional on the deposit of a sum of money (nowadays called an initial margin). ${ }^{99}$ In the rules the initial payment was generally a minimum and the clearing house could impose a higher amount if necessary. ${ }^{100}$ In addition to the original deposit the London Produce Clearing House, like other clearing houses, imposed variable margin requirements. It would fix the market price of a commodity on a daily basis and the margin would be the difference (if a loss) between that price and the contract price. Margins thus varied; they were payable in some cases immediately, certainly within the day. ${ }^{101}$ In its early years deposits and margins were payable either in cash or by lodging approved securities. Later payment requirements could be satisfied by a letter of guarantee from an approved bank. Failure to keep up

\footnotetext{
96 The task was also laborious: it was only in 1960 that the London Produce Clearing House began to mechanise the process with punch cards.

97 Bye-laws of the Liverpool Corn Trade Association Ltd, 1 April 1922, Clearing House Regulations, rr.13-14. There is a short account of London grain futures clearing, with Liverpool comparisons in A.A. Hooker, The International Grain Trade (London : Pitman, 1939) 34-6.

98 Bye-laws of the Liverpool Corn Trade Association Ltd, ibid r.15. For an example: Liverpool Corn Trade Association, Clearing House Committee Minutes, LMM, B/LCTA/7/1, 61, 1 Feb 1926.

${ }_{99}$ Cf. the Liverpool grain trade rules: Bye-laws of the Liverpool Corn Trade Association Ltd, ibid rr.29-30, which gave the parties the decision as to whether to call an original margin from the other side. A suggestion for original margins, to prevent serious over-trading, led to inquiries of the Winnipeg Grain Exchange about its practices - not, note, London - but it was decided the existing rules 'had stood a very thorough test over many years': Liverpool Corn Trade Association, Clearing House Committee Minutes, LMM, B/LCTA/7/1, 23, 30, 31 Mar; 19 May, 1925.

${ }^{100}$ London Produce Clearing House Ltd, Regulations for Coffee Future Delivery Business, May 1888, r.6. 101 r.11.
} 
margin payments entitled the clearing house to close out the party's contracts and to sell any deposited securities without obtaining prior approval. ${ }^{102}$ The securities were thus deposited by way of security, although the rules did not state this expressly. ${ }^{103}$

Settlement occurred in commodity markets in three main ways. ${ }^{104}$ Direct settlement was the most straightforward through the bilateral reconciliation of contractual claims and liabilities. Direct settlement faced no objection at law. If a seller agreed to set off the price of goods supplied against items admitted to be due to him by the buyer, Lord Campbell explained that both would be paid because it was as if the parties had met 'and one of them actually paid the other in coin, and the other handed back the same identical coin in payment of the cross debt.' ${ }^{105}$ Once the price was payable under the contracts the set-off was effective as to both delivery and payment obligations unless there was a difference in price, whereupon one party would have to pay that to the other. In a leading American futures case Holmes J put it pithily: 'Set-off has all the effect of delivery'.106 That was the position in English law as well. In one of the few English cases concerning the commodity markets, in 1925, the judges in the Court of Appeal simply accepted the effectiveness of this contractual provision in the Liverpool cotton rules. ${ }^{107}$

Although effective in law the problem of direct settlement was that, as the volume of trading increased, especially for hedging and speculative purposes, it became impractical without the intervention of a clearing house. ${ }^{108}$ How a clearing house could facilitate direct settlement was demonstrated by the method used in the London Produce Clearing House in relation to coffee futures. ${ }^{109}$ The settlement process was initiated, as typically for clearing houses, by the registration of contracts after the payment of a required deposit. ${ }^{110}$ Following this the clearing house issued to each party a non-endorsable 'certificate of guarantee' in which it declared that it was responsible to both buyer and seller for the fulfilment of the

\footnotetext{
102 r.13. For an example: London Grain Futures, Minute Book No.1, GH MS 23 205/1, 24 Aug 1939. See also E. Bailey \& Co. Ltd. v Balholm Securities Ltd. [1973] 2 Lloyds Rep. 404, 406-7, 415.

${ }^{103}$ Cf. the Liverpool grain trade rules, n 99 above, r.41.

104 J. Moser, Origins of the Modern Exchange Clearinghouse: A History of Some Early Clearing and Settlement Methods at Futures Exchanges, Working Papers Series, Issues in Financial Regulation, Research Department, Federal Reserve Bank of Chicago, WP-94-3, April 1994, 7-15.

105 Livingstone v Whiting (1850), 15 QB 722, 723; 117 ER 632, 632. See J.P. Benjamin, A Treatise on the Law of Sale of Personal Property (London: Sweet \& Maxwell, 7th ed, 1931) 883-84 for other authorities.

106 Chicago Board of Trade v Christie, 198 US 236, 246 (1905).

107 Cooper (Inspector of Taxes) v Stubbs [1925] 2 KB 753, 755. See also Devlin J in F.E. Hookway \& Co. Ltd v Alfred Isaacs \& Sons [1954] 1 Lloyd's Rep 491, 503.

108 T. Ellison, The Cotton Trade of Great Britain, $\mathrm{n} 87$ above, 283-4.

109 The rules of some clearing systems recognised that direct settlement could occur outside their remit, e.g. Beetroot Sugar Association, Rules and Regulations, $8^{\text {th }}$ ed, 1904, r.320. In the 1930s probably a third of the Liverpool grain futures traders were not registered; nearly all perhaps were made and offset by opposite contracts during the day: Working \& Hoos, n 79 above, 141. Although initially with London grain futures members could not marry contracts themselves this was later permitted if done in the ring at the same price. London Grain Futures Minute Book No.1, 2 July 1929, 21-2; 7 Dec 1933, 114, GH MS 23 205/1.

${ }^{110}$ London Produce Clearing House Limited, Regulations for Coffee Future Delivery Business, May 1888, rr.6-7.
} 
contract. ${ }^{111}$ Under rule 14 of the rules settlement occurred by a contracting party handing the clearing house two certificates of guarantee for the same delivery, in one of which it was named as buyer and the other seller. Absent any default the clearing house was then 'bound... to make up accounts at once and to pay or place to the credit of the contracting party, any balance due'. That balance was made up of the margins, which needed to be repaid, and brokerage, but with a discount if payment was prior to the delivery date. ${ }^{112}$ If a contracting party was unable to enter an off-setting transaction to settle in this way it needed to accept tender of the coffee (unless it could subsequently re-sell. ${ }^{113}$ ) Settlement then involved passing of the dock or wharf warrants, representing the goods.

After direct settlement a second method used on the commodity markets was ring settlement. Its advantage was to increase the number of potential counterparties available to settle. Where A sold to B, B to C and C to A the same amount of a commodity for delivery on the same date, bringing $\mathrm{A}, \mathrm{B}$ and $\mathrm{C}$ together in a ring meant that the different sales would cancel each other out and all that was needed was for the parties to pay the price differences. The ring could involve many more parties than three and price differences could be netted so that payments were reduced. Netting of price differences was facilitated by striking a settlement price, representative of prices in the market, and parties then needed to pay only the difference between that and the price of their trades. Ring settlement did not need an organised clearing house. In some markets there is evidence of traders meeting after a market closed to trace contracts back so as to form rings and outdoor clerks being sent around to different offices to close up a series of trades. ${ }^{114}$ The London Metal Exchange did not have a clearing house and seemed to use a form of ring settlement, devised in 1909 by a member of its committee.

Each ... member began to submit a daily confidential return to the Secretary of the Exchange showing the warrants he owed or was due to receive from each other member on the prompt date together with the balance of his transactions with the market as a whole. The Secretary was able to fit these returns together, isolating the members who were long in the market, and direct them as to whom delivery of warrants should be made. Cash differences arising from transactions were paid privately by the members concerned. ${ }^{115}$

Ring settlement was facilitated where a clearing house existed, not only in the organisation of rings but in netting price differences. ${ }^{116}$ It was a regular feature of

\footnotetext{
111 rr. $1,8$.

112 rr. 14,20

113 rr.16, 18.

114 n 25 above, 50-1.

115 Economist Intelligence Unit, A History of the London Metal Exchange (London: The Unit, 1958) 63. R.B.

Forrester, 'Commodity Exchanges in England', Annals, v.155, May 1931, 205.

116 H.J. Loman, 'Commodity Exchange Clearing Systems' Annals, v.155, May 1931, 101-2.
} 
clearing contracts in the London and Liverpool grain markets. Their clearing houses would match up trades to form rings as best they could. ${ }^{117}$

The third, and typical method of settlement when the London and Liverpool commodity markets matured, was settlement by novation. At its simplest if a party had bought and sold equal amounts of a commodity for delivery in the same period, it could drop out if its buyer and seller were brought together, and it paid anything owing on the two transactions. Novation as a legal technique was familiar to lawyers from partnership law. ${ }^{118}$ New partners undertook, and retired partners relinquished, contractual obligations with the acknowledgement of third parties dealing with the firm. There were also instances of the assignment of the business of one insurance company to another, with the policy holders assenting to the transfer of their policies. ${ }^{119}$ By the time the London and Liverpool clearing houses were being established, novation was being recognised by the highest of authorities. ${ }^{120}$ Initially, however, clearing house rules did not specifically mention novation and there may have been some doubts about contracting for it in advance in this way. Although Pollock had proferred the view in his Principles of Contract that apart from novation in the proper sense the creditor might bind himself once and for all in the original contract to accept a substituted liability at the debtor's option, other writers were not as bold.121 When United States courts considered the substitution of parties to settle commodities contracts they upheld its legality on the basis of market practice in the Chicago Board of Trade rather than novation. ${ }^{122}$ It was not until 1915 that an English court approved novation in the context of commodities markets.. ${ }^{123}$

Novation was mentioned expressly in the rules of the London Produce Clearing House, once it adopted novation as a technique rather than direct settlement through presentation by a party of equivalent buy and sell certificates of guarantee. Thus rule 1 of the 1928 regulations for settling futures transactions in cocoa provided that in consideration of the registration of a contract, and the guarantee the clearing house gave both buyer and seller as to its fulfilment, both parties respectively agreed with each other and the clearing house to accept 'by way of novation' such other sellers and buyers as the clearing house might appoint for the sale or purchase of the commodity mentioned in the contract. ${ }^{124}$ Rule 13

117 e.g. Bye-Laws of the Liverpool Corn Trade Association Ltd, n 97 above, r.18 provided: 'The Secretary shall have power to vary the arrangements of the contacts on a string whenever all or any number of them are capable of being formed into a ring'.

118 e.g. Wilson $\mathrm{v}$ Lloyd (1873) LR 16 Eq 60.

119 e.g. Re International Life Assurance Society \& Hercules Insurance Co ex p. Blood (1870) LR 9 Eq 316; Re European Assurance Society, Miller's Case (1876) 3 Ch.D. 391.

120 Scarf v Jardine (1882) 7 App.Cas. 345, 351.

${ }^{121}$ F. Pollock, Principles of Contract (London: Stevens, 2nd ed., 1878) 190. S.M. Leake, An Elementary Digest of the Law of Contracts (London: Stevens and sons, 1878) 791 could have been read as supportive but Chitty did not acknowledge novation until the $12^{\text {th }}$ edition in 1890 (at 862).

122 Oldershaw v Knowles, 6 Ill App 325 (1880), affd 101 Ill 117 (1881). See also Wolcott v Reeme, 44 Ill App 196 (1892).

123 Jager v Tolme and Runge and the London Produce Clearing House Ltd. [1916] 1 KB 939.

${ }^{124}$ London Produce Clearing House Ltd, Regulations for Future Delivery Business in Cocoa, April 1928. To the same effect see novation for rubber sales in the contract set out in S.W. Dowling, The Exchanges of London (London: Butterworth, 1929) 117-8. 
of the regulations then provided that if a party ('the middle party') requested a settlement of contracts in which it was on the one hand a buyer, and on the other a seller, for the same amount of cocoa for the same month of delivery, it ceased to be under any liability to receive or deliver that commodity and its seller and buyer were deemed to contract with each other.

The operation of novation in this way was still in the rules of the London Produce Clearing House in the early 1970s. ${ }^{125}$ What had fallen by the wayside, although it was to be revived as the norm once the (renamed) London Clearing House began to clear financial futures in the 1980s, was novation whereby the clearing house itself was substituted for each of the parties (called 'complete clearing' in the United States). Under this arrangement a seller-buyer contract was transformed into two contracts, a seller-clearing house contract and a clearing house-buyer contract. An advantage of substitution of the clearing house in this way was that it, not the parties, carried the credit risk. Sellers and buyers were now bound to the clearing house, which had taken the place of their original counterparty. If either party failed the clearing house would bear the loss directly.

One example of its early use was in sugar clearing just prior to World War I. The 1913 version of the LPCH rules for clearing futures business in beetroot sugar provided for substitution of the clearing house once settlement occurred by a party handing in buy and sell certificates of guarantee for the same delivery date.

Such settlement shall have the effect that all rights and liabilities of the contracting party - as regards the respective contracts - shall devolve upon the [Clearing House] and that the liability of the contracting party to the [Clearing House] or to any client thereof shall terminate. Buyers and sellers (as the case may be) of the oldest open contracts, in the numerical order of the [Clearing House's] Register shall then take the place of the counterparty so liquidated...

The Court of Appeal averted to these arrangements in 1916 although it did not refer to the clearing house rule. ${ }^{126}$ Rather it relied on the contract of the Sugar Association of London, for sale of beetroot sugar $88^{\circ}$, which was cleared under $\mathrm{LPCH}$ rules and which contained a clause along the same lines. The Court of Appeal accepted that this meant that the position was the same as if the plaintiff had made a contract with the clearing house and the liability of the original sellers to the plaintiff was at an end.

125 London Produce Clearing House Ltd., General Regulations for Future Delivery Business and Byelaws for Options, 1972, r.13. See E. Bailey \& Co. Ltd. v Balholm Securities Ltd. [1973] 2 Lloyd's Rep 404, 407-8.

126 Jager v Tolme \& Runge and the London Produce Clearing House [1916] 1 KB 939. See also Smith, Coney \& Barrett v Becker, Gray \& Co [1916] 2 Ch.86. 


\section{DefaulT}

Party default was always a threat to clearing houses. If one of the parties was unable to settle when the time arrived this would have a domino effect because of the network of transactions which that party was likely to have entered into. Should a party be in default - fail to pay a margin or a price difference, be unable to tender under a contract - the rules enabled the clearing house to close out its contracts. On this occurring the defaulting party would be excluded. What then happened is illustrated by the actions of the London Corn Trade Association clearing house on failure of the grain dealer, Bovill \& Sons, in 1925. The clearing house decided on the price, $42 / 6$ for 24 July, the day the firm collapsed. That price was then used for the contracts closed out between Bovill and their immediate sellers and buyers. But what of other contracts appropriated to the cargo of SS River Tyne, and therefore in the string? The clearing house had only been operating several years and some firms urged that $42 / 6$ should be used for all contracts on Bovill strings. Following standard practice elsewhere the clearing house rejected this and said all other contacts on Bovill strings, apart from immediate sellers and buyers with Bovill, had to be fulfilled at the prices agreed.127

There was no loss if a defaulting party was in profit on its contacts. ${ }^{128}$ If not it was its immediate counterparties who in the first instance were exposed to loss through the defaulter being unable to pay. A novation would be unwound so it was the original, not the substituted, counterparty who was exposed to loss. ${ }^{129}$ The policy behind the approach was that parties were responsible for evaluating the creditworthiness of their immediate counterparties. However, the rules differed and many attempted to mitigate the exposure to loss of immediate counterparties to a defaulter. Under the early rules of the Liverpool cotton exchange, although the defaulter bore the loss the clearing house had a discretion as to how to fix the prices and dates 'with due regard to "set offs" at which all payments shall be made to the insolvent's estate'. 130 The Liverpool grain trade tried to spread losses: if more than one party's contracts were affected by the defaulting party the clearing house 'shall apportion the contracts closed by him, and the loss, if any, incurred thereby, among such members'. ${ }^{131}$ The approach of the London Produce Clearing House tried to spread the loss equitably. It could close out contracts or invoice back on a party's default, and all buyers and sellers with uncovered

${ }^{127}$ London Corn Trade Association, Clearing House Board, Minute Book No.1, 11 Aug 1925, GH, MS 23, 189.

128 e.g. closing of a number of cif strings involving Strauss \& Co. Ltd. (in liquidation): Liverpool Clearing House Committee, LMM, B/LCTA/7/2, 59-60, 7 February 1935. And there was only a small deficiency (£9.1.7) on Strauss' London dealings! London Grain Futures, Minute Book No.2, GH MS 23 205/1, 14 Feb 1935.

129 e.g. London Corn Trade Association, Clearing House Board, 5 June 1933, GH, MS 23, 189.

130 Constitution, Laws and Usages of the Liverpool Cotton Brokers Association, 1881, Clearing House Rules, rr.17-18. See also Rules Relating to Cotton Sold to Arrive, r.12; Liverpool Cotton Brokers Association, Letter from Mr Hobson and Report of the Clearing House Committee, 15 Aug 1879, LRO, 380 COT $4 / 77$.

131 Bye-Laws of the Liverpool Corn Trade Association, 1922, Clearing House Regulations, r.19. See also r.20. 
positions for the same delivery had to share the losses pro tanto (or to the nearest fraction) and take the place of the counterparty to the defaulter's contracts so closed. ${ }^{132}$ None of these rules for commodities went as far as rule 177 of the Stock Exchange which, at the turn of the century, obliged members to pay price differences in a defaulter's favour into a fund, rather than to the defaulter, for distribution to members with price differences in their favour. ${ }^{133}$

Settlement risk through party default was guarded against in various ways. Those without financial integrity might not be admitted to the clearing arrangements in the first place. There are instances in the records where members had their ability to register contracts withdrawn through their failure to pay margins, thus raising doubts about their credit. Initial deposits on the registration of contacts and variable margins were devices to curb parties from assuming risks beyond their capacity to cover. Periodic settlement was another device. Originally it was adopted by about sixty brokers in Liverpool cotton in December 1883 as a reaction to attempts to corner the market. They formed themselves into a Settlement Association with its own bye-laws and rules although eventually the Liverpool Cotton Association incorporated periodic settlement into its rules. ${ }^{134}$ Periodic settlement imposed a check on speculators without capital from incurring an excessive exposure which could threaten the market: what they owed became a net amount, not all that they had contracted for in a given period.

Prevention would not always work so clearing houses built up compensation schemes for parties suffering through the default of other market participants. The financial capacity of clearing houses to compensate wholly or in part derived from three sources, although the mix varied. First, there were the capital and reserves; secondly, the deposits and margin payments; and thirdly other sources like any security taken. In the case of the London Produce Clearing House the capital and reserves were considerable, although that was not the case with other clearing houses which operated differently. Moneys raised from deposit and margin payments were there to contribute to liabilities when a party defaulted. In the case of the London Produce Clearing House these were funds to back the guarantee it gave on any transaction. From 1921 the clearing house would accept a bank guarantee in approved form as cover for deposits and margins. ${ }^{135}$

With some clearing systems, parties might tap deposits and margins on default of a counterparty more directly, although payment might still be a matter of discretion on the part of the clearing house. The Liverpool Corn Trade Association rules provided that all margins payments were held as security for contracts until fulfilled or closed, with the amounts being paid to parties entitled

132 London Produce Clearing House, Regulations for Future Delivery Business in Cocoa, April 1928, rr.11, 15.

133 Beckhuson \& Gibbs v Hamblet [1900] 2 QB 18, 22, per Kennedy J. on appeal [1901] 2 KB 73.

${ }_{134}$ T. Ellison, Gleanings and Reminiscences (Liverpool: Henry Young \& Son, 1905) 355-6; n 19 above, 57. See also S. Chapman, The Lancashire Cotton Industry (Manchester: Manchester University Press, 1904) 131-2.

135 GL, MS 3641/5, 216, 7 April, 233, 31 Oct 1921. It was an early form of demand guarantee - 'At the request of [ ] we undertake to pay you on demand up to $f_{0}[$ ]...' - drafted by business people, although submitted to Coward \& Co, solicitors, for approval. See Tate \& Lyle Refineries Ltd. v International Commodities Clearing House Ltd [1975] 1 Lloyds Rep 477, 479. 
to receive them. ${ }^{136}$ Under the insolvency clause, if a party became insolvent or had a receiver appointed the clearing house had discretionary power to pay the margin payments to the other party so much as in their opinion they were entitled to. ${ }^{137}$ When one of the leading grain firms, Shipton, Anderson \& Company, collapsed in 1937 owing nearly $f_{3} 3000$ to the clearing house, its liquidator sought to reclaim the margin payments the firm had made so as to be able to pay other creditors of the company. The clearing house persuaded the liquidator to abandon the claim after referring him to its rules, i.e. that margin payments of a failed member went to that member's creditors in relation to claims under grain contracts. ${ }^{138}$

So far we have seen that clearing houses used a variety of sources so as to compensate those adversely affected by the default of one dealing in the commodity markets. But compensation might still be a matter of discretion on the part of the clearing house. What of claims as of right by those adversely affected by default? From its inception in 1888 the London Produce Clearing House gave a guarantee that parties would meet their contractual obligations. 'The Company shall guarantee to both buyer and seller the fulfilment of any contract which has been registered in its books.' ${ }^{139}$ The process by which the London Produce Clearing House guaranteed performance of contracts continued in the inter-war period and into the years after World War II. ${ }^{140}$ A guarantee from the late $1950 \mathrm{~s}$ reads in part:

Certificate of Guarantee. For [ ] Buyer. London Produce Clearing House, Limited subject to its Regulations and Conditions, guarantees to you the fulfilment by the Seller of the Contract No. [] for the delivery of 50 Tons of ... Raw Cane Sugar ... delivered cif London and/or Liverpool ... In accordance with the Rules, Conditions and Bye-Laws of the United Terminal Sugar Market Association

Delivery: [date]. Price $[£]$. London. Authorised Signatory. ${ }^{141}$

There was no question about the enforceability of this kind of guarantee in English law. The certificate itself performed the obvious function of satisfying section 4 of the Statute of Frauds, 1677: it was the written memorandum or note,

\footnotetext{
136 r.41.

137 r.36.

${ }^{138}$ Liverpool Corn Trade Association, Clearing House Committee 1933-1941, LMM, B/LCTA/7/2, 9, 11 July, 8 Aug 1935, 78-9, 81, 84.

139 e.g. London Produce Clearing House Ltd, Regulations for Coffee Future Delivery Business, May 1888, r.1. We have seen that exceptionally with sugar pre-World War I the clearing house stood as a central counterparty on contracts so there was direct legal liability when a party defaulted.

${ }^{140}$ London Produce Clearing House Ltd, Regulations for Future Delivery Business in Cocoa, April 1928, rr.1, 5,7 .

${ }^{141}$ Kindly provided by David Hardy, chief executive of the London Clearing House. The certificate is undated but seems related to the No.2 (Preferential) raw sugar contract, introduced in 1959: GL Rees \& D.R. Jones, The History of London Commodity markets (London: Commodity Analysis Ltd, 1978) 247.
} 
signed on behalf of the clearing house, setting out the details of the contract being guaranteed. ${ }^{142}$

The Liverpool grain trade adopted a different model, insurance. The clearing house paid a proportion of the registration fee for contracts to an insurance fund, capable of being allocated in the case of default of any member to make payment to counterparties in respect of a registered contract. ${ }^{143}$ The insurance fund was operated by a specially constituted organisation, the Liverpool Grain Contract Insurance Company Ltd. The insurance company paid up to a specific limit (e.g. at one point $£ 100$ for each separate contract) and then, having had a party's claim against the defaulter assigned to it, pursued what it could. If it did recover, after recouping its costs it was obliged to compensate parties for the unpaid balance of their loss. ${ }^{144}$ In the Shipton, Anderson \& Co failure the clearing house refused to allow the insurance company recourse to the security which the clearing house held from the firm. ${ }^{145}$ Legally, this was perfectly justified since it was the clearing house which held the security, not the counterparties to whose claims the insurance company had been subrogated. Relatively few claims seem to have been made on the insurance fund. ${ }^{146}$

\title{
MAINTAINING MARKET INTEGRITY
}

\begin{abstract}
'He did not think in any abstractions, but in deals, in sales, in transfers and in gifts. He thought in shares, in bales, in thousands of bushels, in options, holding companies, trusts, and subsidiary corporations, and as he went over it he knew they had plenty...

He had been admirably endowed for a speculative career because he had possessed extraordinary sexual vitality which gave him the confidence to gamble well; common sense, an excellent mathematical brain, a permanent but controlled skepticism; a skepticism which was as sensitive to impending disaster as an accurate aneroid barometer to atmospheric pressure; and a valid time sense that kept him from trying to hit tops or bottoms. These, coupled with a lack of morals, an ability to make people like him, had carried him to where he was now.' 147
\end{abstract}

Maintaining market integrity in the light of purely speculative transactions was not regarded as a matter where public policy should contribute. Speculation in mainstream opinion was, at worst, a necessary evil. If action were to be taken it was to be what we would these days call self-regulation. Market rules such as regular settlement days and deposit and margin payments, with their dampening effect on speculation, have already been considered. Cornering the market gave

\footnotetext{
142 e.g. S.A.T. Rowlatt, The Law of Principle and Surety (London: Sweet and Maxwell, 1898) ch.3; Earl of Halsbury, Laws of England (London: Butterworth \& Co, 1911) 456-72.

143 Bye-Laws of the Liverpool Corn Trade Association Ltd, n 97 above, r.21. See also Liverpool Grain Contract Insurance Co. Ltd., LMM, B/LCTA/27/1-2 (1940-64).

${ }^{144}$ Liverpool Corn Trade Association, Bye-Laws Relating to Grain Futures. Insurance of Contracts, r.41. LMM, B/LCTA/42/31.

145 Clearing House Committee 1933-1941, LMM, B/LCTA/7/2, 27 January 1938, 171.

146 W. Hudson, 'Futures' Markets and Contracts', Liverpool Corn Trade Association Lectures - No.4, c.1948, LMM, B/LCTA/34/8.

147 E. Hemingway, To Have and Have Not (1937)
} 
rise to a limited action by commodity markets around the turn of the nineteenth century. In the early 1890s the London Produce Clearing House adopted regulations for a corner clause in contracts for Santos coffee. ${ }^{148}$ That was emulated in 1911 for contracts it cleared in beet sugar. The clause was drafted by members of the clearing house although rather unusually counsel's opinion was obtained on its effectiveness. ${ }^{149}$ Similarly, on the Liverpool wheat market prevention of corners was through rules prescribing generous treatment of short sellers who, as victims of a corner, defaulted: no penalty could be imposed for default, settlement being ordered at around the spot price, and for sellers on cif terms invoicing back was permitted. In both cases the buyers attempting a corner would be thwarted. The London Metal Exchange went further. It adopted a rule, rule $\mathrm{H}$, which provided that if in its opinion a corner was being attempted, it could investigate and 'take whatever action it considers proper to restore equilibrium between supply and demand'. ${ }^{150}$ This self-regulatory approach of the London Metal Exchange is probably explained by the limited membership of the exchange and the fact that because most were also heavily involved in the physicals market as well they would suffer adversely if cornering occurred. ${ }^{151}$

Law was a distant backstop to market integrity. It was reserved for egregious behaviour bordering on the fraudulent. On the market itself fraud included rigging the market to avoid true prices and where dealers cheated their principals, employers or each other. ${ }^{152}$ Rigging the market, by the deliberate use of false transactions or spreading fictitious information to influence prices, was held to be an offence in England early in the nineteenth century. The leading case, involving false rumours to influence the price of government securities, dated from the Napoleonic era. ${ }^{153}$ In the grain markets rigging was said to be frequent prior to the repeal of the Corn Laws in 1846. It was done to take advantage of the lower duty payable in imported grain when the market price was high. ${ }^{154}$ But offenders avoided prosecution. In 1834 the Comptroller of Corn Returns gave evidence to a parliamentary select committee of fictitious sales to raise the price of rye, so as to be able to import foreign rye at the lower duty permitted under the corn laws. A prosecution had been submitted to the Attorney-General and Solicitor-General

\footnotetext{
148 London Produce Clearing House, Board Minutes, GH, MS 3641/2; 12/4/1893, 115.

149 ibid MS 3641/4, 27,11,11, 345; 29/11/11, 346; 27/11/11, 345; 22/1/1912, 353. The clause read: 'If in the opinion of the [clearing house] an operation be in progress to corner $88 \%$ beet sugar, then the seller on the contract shall be entitled to demand that the sugar be invoiced back to him at a price which shall be the refining value to be found by the Committee of the Sugar Association of London Clearing Department, or by Experts named by Directors, plus 20\%.

150 R. Gibson-Jarvie, The London Metal Exchange (Cambridge: Woodhead-Faulkner for Metallgesellschaft AG, 1976) 35-8, 52-3.

151 S.C. Pirrong, The Self-Regulation of Commodity Exchanges: The Case of Market Manipulation' (1995) 38 J.Law \& Econ. 141, 191-2.

152 e.g. London Corn Trade Association, Clearing House Board, GH, MS 23/189, 18 July 1933 (employee trading on account in false name).

153 R. v De Berenger (1814), 3 M \& S 67, 105 ER 536.

154 G. Dodd, The Food of London (London: Longman, Brown, Green and Longmans, 1856) 174.
} 
but although satisfied of a fraud they decided against prosecution because of uncertainty about getting a conviction. ${ }^{155}$

\section{CORNERING MARKETS}

The idea of cornering a market entered popular consciousness. It was the purchase by a syndicate or ring of enough of a commodity or securities so as to drive speculative sellers into a corner and compel them to buy at a high price in order to complete the sales they had made. There was Biddle's celebrated attempt to control the cotton market in the United States and England with its adverse consequences for the reputation of the Bank of the United States. ${ }^{156}$ Corners in the United States grain market in the nineteenth century were also known, the most notable being that in 1898 by Joseph Leiter, brother in law to George Nathaniel Curzon, later Viceroy of India. ${ }^{157}$ The London and Liverpool commodity markets were not immune. In the late 1880s there was an unsuccessful attempt by M. Pierre Secretain, manager of a leading firm in the French metal industry, to corner the world supply of copper and tin, which involved dealings on the London Metal Exchange. ${ }^{158}$ Corners in the Liverpool cotton market were a matter of considerable comment. ${ }^{159}$

Where did English law stand on the subject of cornering? Cornering a market is generally legitimate - that was the gist of the short entry on the subject in the first edition of Halsbury's Laws of England published in 1913.160 And certainly when English courts had been presented with claims for losses arising from cornering operations in the stock exchange they were reluctant to assist. Not only had there to be a fraudulent representation or a conspiracy, but that had to be intended to cause, and in fact must have caused, the loss the plaintiff occasioned to fulfil his bargain because he had to pay a premium to the cornering ring.

If the civil law was ineffective in practice in relation to cornering, the criminal law was never tested. In theory corners where fraudulent devices were resorted to were indictable as conspiracies. However, when the great pepper corner scandal of the 1930s presented itself as a laboratory to test this the prosecution went down a different avenue. One of the leading characters was Garabed Bishirgian, who had

\footnotetext{
155 Report of the Select Committee on Sale of Corm, Parliamentary Papers, 1834, No.517, vii, 1, 208.

156 e.g. W.B. Smith, Economic Aspects of the Second Bank of the United States (Cambridge, Mass: Harvard University Press, 1953) 195-202, 258-9.

157 Liverpool Corn Trade Association, n 79 above, 20-1. See J. Lurie, Chicago Board of Trade 1859-1905 (Urbana: University of Illinois Press, 1979) 52-3, 67-8; J. Markham, History of Commodity Futures Trading and its Regulation (New York: Praeger, 1987) 5-6; W.G. Ferris, The Grain Traders. The Story of the Chicago Board of Trade (East Lansing, Michigan: Michigan State University Press, 1988) 33-4, 39-44.

158 D. Avery, Note on Queen Victoria's Birthday. The Story of the Rio Tinto Mines (London: Collins, 1974) 156; Economist Intelligence Unit, n 115 above, 85-89.

${ }^{159}$ E. Guthrie, 'The Effects upon Trade of the operation called "Cornering" in relation to commodities', Transactions of the Manchester Statistical Society, Session 1881-82, 30 Nov. 1881, 31-2; W.W. Biggs, 'Cotton Corners', Transactions of the Manchester Statistical Society, Session 1894-95, 13 March 1895, 123, 127-134

${ }^{160}$ Earl of Halsbury, The Laws of England (London: Butterworth, 1913) v.27, 264. cf. the United States where contracts having a corner as their object were not enforced (Sampson v Shaw, 101 Mass. 145 (1869)) or anti-trust legislation was invoked (US v Patten, 226 US 525 (1911).
} 
conducted business in the City for many years. His co-conspirator was John Howeson, chairman of the London Tin Corporation, Initially pepper was acquired from early 1933, it seems, by Bishirgian on behalf of William Henry \& Co, which he and Howeson were able to control. To further the scheme they acquired the commodity brokers, James and Shakespeare Ltd. which they then took public in August 1934, ostensibly to raise funds for general expansion but in fact to continue the cornering operation. ${ }^{161}$ The corner failed because the ring had underestimated the stocks of pepper they needed to corner the market and because of a large inflow of pepper to London.

The crisis came to a head in January 1935. James and Shakespeare was in financial difficulty - the General Produce Brokers' Association declared it to be in default on 8 February - and a number of other commodity brokers hovered precariously. Some of the banks were also exposed, in particular the Midland Bank (now part of HSBC) having advanced something like one million pounds to James and Shakespeare. The General Produce Brokers Association, and then an ad hoc committee of commodity brokers, appealed to the clearing banks to accommodate the firms threatened to avert widespread failures in the market. Under pressure from the Bank of England the banks agreed. ${ }^{162}$ Trading was suspended for a week to break the jam. A pepper pool, the London Pepper Sales Control Committee, was formed to dispose of the pepper over the following years. A few commodity brokers still went under. ${ }^{163}$

When a criminal prosecution ensued it was not for any offence of trying to corner the market for in English law there was none. Nor was it for conspiracy. Rather the prospectus which the principals had caused James and Shakespeare Ltd to issue for the acquisition of Williams Henry \& Co and Bishirgian \& Co was alleged to have been false and therefore in breach of section 84 of the Larceny Act 1861. Perhaps it is not surprising that the prosecution should look to that, rather than conspiracy, since the section had grounded the successful prosecution of Lord Kylsant a few years earlier. ${ }^{164}$ The jury convicted and the defendants were imprisoned. An appeal was unsuccessful. 165 Never one to mince his words, the Lord Chief Justice, Lord Hewart, said that morally and legally the transaction did not differ, other than in dimensions, from 'the office boy who takes a half-crown from the till because he has a good thing for the Grand National'. ${ }^{166}$ The purpose for which the money was wanted here, and to which it was applied, 'was the bolstering up of a very ambitious scheme - which failed - to control the pepper supply of the world'. The upshot of the scandal was that, under pressure from the Bank of England, a futures marked was inaugurated for pepper in 1937, with

\footnotetext{
161 'James and Shakespeare Ltd. Liquidation Meetings', The Times, 5 Ap. 1935, 4; 'Liquidation of James and Shakespeare Ltd. Senior Official Receiver's Report', The Times, 10 July, 1935, 4.

162 R.S. Sayers, The Bank of England 1891-1944 (Cambridge: Cambridge University Press, 1976) 544-5; D. Kynaston, The City of London vol 3 (London: Chatto \& Windus, 2000) 425-9.

163 'City Pepper Crisis', The Times, 9 Feb, 1935, 12; J.F. Adair and Co. Ltd. 'Senior Official Receiver's Report', The Times, 16 July 1935, 5.

164 R. v Kylsant [1932] 1 KB 442.

165 R. v Bishirgian [1936] 1 All ER 586.

166 ibid 594.
} 
clearing and settlement through the London Produce Clearing House. ${ }^{167}$ The intention was to regularise dealings within an organised market. There was no attempt to follow the United States example, where from 1936 cornering or attempting to corner a commodity in interstate commerce was a criminal violation under federal law. 168

\section{WAGERING}

For commodity markets wagering was a constant threat, the legal hammer invoked by a disgruntled individual to avoid a transaction on the basis that it was in contravention of public policy or in breach of the Gaming Acts. Bryan v Lewis ${ }^{169}$ was an inauspicious beginning, just as modern commodities markets were emerging. In February 1823 the plaintiff had the defendant broker sell some nutmeg, which at the time he did not own. The broker sold the nutmeg for delivery in May, clearly a forward contract. Subsequently in March the plaintiff bought nutmeg. In May warrants for the nutmeg were tendered to the purchaser, who was unable to pay for them, apparently because he was a minor and 'a person of no property or expectations'. Counsel for the plaintiff argued that not to enforce the plaintiff-broker contract would upset dealings at the Royal Exchange, at that time where many commodities were traded. Nonetheless Abbott CJ (later Lord Tenterden) ruled at nisi pruis that it was a wager, and therefore unenforceable at common law, for a person to sell goods to be delivered at a future time if he did not then have the goods, had not entered into a prior contract to buy them, had no reasonable expectation of receiving them by consignment, but meant to go into the market to obtain them.

Bryan $\mathrm{v}$ Lewis came at a bad time. The 1820s had experienced a period of intense speculation both in commodities, in particular tallow, and foreign government securities. In 1824 and early 1825 there was a mania in company promotions, generally a swindle, extending to mining and other ventures in South America. The bubble eventually burst, leading to a severe depression from the second part of 1825, and involving the collapse of many banks and a stagnation in manufacturing. All this cannot but have influenced judicial attitudes. Indeed, in Bryan $\mathrm{v}$ Lewis Lord Tenterden specifically mentions the distress in the community of the last twelve months, which he asserts 'would have been avoided' 170 if his view of the law, rendering wagering contracts unenforceable, had been acted upon. Within a decade, and in a more benign economic climate, the Tenterden view was discredited. ${ }^{171}$ It was finally 'quite exploded'172, as Judah Philip Benjamin

\footnotetext{
167 Oscar R. Hobson, How the City Works (London: 'News Chronicle' Publications Dept, 1938) 124; Sayers, n 162 above, 546.

168 Commodity Exchange Act, s.116, 49 Stat at 1501. See Great Western Food Distributors v Benson, 201 F 2d 476 (7th Cir, 1953), cert. denied 345 US 997 (1953).

169 (1826) Ry \& Mood 386; 171 ER 1058.

170 See D. Kynaston, The City of London vol 1 (London: Chatto \& Windus, 1994) 49-55, 63-75.

${ }^{171}$ See Wells v Porter 2 Bing (NC) 722; 132 ER 278, a case involving Spanish and Portuguese banks.

172 Benjamin's Sale of Personal Property (London: H. Sweet, 4th ed, 1888) 86.
} 
put it, in a case involving the sale of shares, Hibblewhite $\mathrm{v}$ M'Morine, ${ }^{173}$ although commodities are referred to throughout, and the headnote is formulated in terms of a rule for the sale of goods, not shares. To Baron Parke Lord Tenterden's views were contrary to law and influenced by the 1825 depression. There was no injury to the public: '[i]ndeed, the fewer the restraints imposed upon contracts the better'. ${ }^{174}$ Alderson B was blunt: the Tenterden view would 'put an end to half the contacts made in the course of trade'. ${ }^{175}$ As for Maule B, he had often heard the Tenderden approach spoken of with great suspicion by lawyers as against principle and by mercantile men as against commercial convenience.

So at common law such transactions were in the clear. But futures trading was not out of the legal woods yet. Unless carefully structured there remained a threat well into the twentieth century that it would constitute breach of the Gaming Act in 1845. ${ }^{176}$ The Act was not directed at commercial activity but at evils like common gaming houses. ${ }^{177}$ However, the Act had a general prohibition, section 18 under which all contracts or agreements by way of gaming or wagering were null and void, and no legal action could be brought to recover any money or thing allegedly won or staked in relation to any wager. When the issue came before the Court of Common Pleas in 1852, in Grizewood v Blane, Serjeant Best cited Hibblewbite v M'Morine and argued that the transaction was not within section 18, any more than if it related to wheat or any other article of commerce or manufacture. ${ }^{178}$ However, the judges upheld the direction to the jury that it was a wager and void if the parties did not really intend at the time of the transaction to purchase or sell the shares in question.

The legal solution to Grizewood v Blane seemed to be to cast contracts in such a way that ostensibly at least there was always an intention to deliver what was sold, whatever might happen subsequently with an off-setting transaction. This was upheld in the leading case of Thacker v Hardy ${ }^{179}$ in 1878. Grizewood v Blane was distinguished, indeed effectively overruled. Bargains where the parties might gain or lose according to the happening of a future event were not in themselves objectionable for what was wrong with the sale or purchase now of next year's apple crop? 180

Thacker $\mathrm{v}$ Hardy was not the end of the line. A considerable number of cases involving stocks and shares followed where those wishing to avoid liability raised the Gaming Act. Some were successful. The courts went beyond the face of the documents or the rules of the exchange to find the 'real' intention of the parties,

173 (1839) 5 M \& W 462; 151 ER 195. The plaintiff failed on other grounds: (1840) 6 M \& W 199; $151 \mathrm{ER}$ 380.

174 Reported in (1839) LJ Ex 271, 273.

175 Alderson B repeated this view in Mortimer v M'Callan (1840) 6 M\&W 57, 76; 151 ER 320, 328. See Lord Arbinger CB to similar effect at 70, 326.

1768 \& 9 Vict. c109. See H.G.H. Stutfield, The Law Relating to Betting, Time Bargains and Gaming (London: Waterlow \& Sons, 1892) 100.

177 Report from the Select Committee on Gaming, Parliamentary Papers, 1844, No.297, v-vi.

178 Grizewood v Blane (1852) 11 CB 526, 539, 138 ER 578, 583. See also Barry v Croskey, supra.

179 (1878) 4 QBD 685. See also Cooper v Neal (1878) 48 LJR (QB) 292n (CA).

180 ibid 692, 696, per Bramwell, Cotton LJJ. 
that only differences would be paid, and that was wagering. ${ }^{181}$ This conflict between the formal and subjective intention in the stock market cases was never satisfactorily resolved.

When in the 1920s the English Court of Appeal finally examined the validity of futures dealings on commodities markets it was not as a result of a direct attack but in the context of a tax appeal. ${ }^{182}$ The taxpayer was employed by a cotton broker in Liverpool. The issue was how profits he made from private futures dealings on the Liverpool, New York and New Orleans cotton exchanges ought to be assessed for tax purposes. ${ }^{183}$ The special commissioners for income tax had found as a fact that they were gaming transactions and were entered by him with no intention of taking actual delivery of cotton or using them as hedges. Notwithstanding this Pollock MR adopted a robust approach. These were real transactions, with real parties, which the dealer or broker could have implemented at any moment, and gambling only in a loose or colloquial sense. Most importantly Pollock MR rejected the subjective approach in some of the cases involving stocks and shares: ' $[T]$ he purpose for which he made them did not alter the character or nature of the contracts that he did make...'.184 Warrington and Atkin LJJ were more circumspect given the commissioners' findings, but still regarded them as real transactions for, whatever the intention of the taxpayer, there was no evidence that his counterparties did not intend to take delivery of cotton.

A month later McCardie J adopted an equally robust approach in a case involving a direct attack on futures dealings on the London Metal Exchange. ${ }^{185}$ In formulating a test McCardie J erected a very high hurdle for challengers: transactions would only be unenforceable if the parties intended that there should be no legal bargain and no right to demand payment of differences, except as a moral right. As long as the parties intended to enter into a legal contract, which gave legal rights and imposed legal obligations, it was enforceable, despite being of a speculative character. In 1936 Hilbery J considered transactions on the Liverpool Cotton Exchange impugnable on either objective or subjective grounds. A member of the public (albeit a businessman) was invited by someone employed on a half commission basis by the plaintiff firm, members of the exchange, to have a gamble in cotton futures for which the firm would (and did) provide credit. Yet here the difference with American law came into play, the effect of the Gaming Act being to make transactions void, not illegal. As Hilbery J put it, once he was satisfied that the firm entered the transactions as brokers, then their claim was for an indemnity from their principal. The firm might have enabled the defendant to gamble but as agents were not directly themselves a party to a contract where it was intended only differences would be paid. 186 The upshot of all this was that by World War II futures dealings on the commodities exchanges were legally safe.

\footnotetext{
181 e.g. Universal Stock Exchange Ltd. v Strachan [1896] AC 166; Re Grieve [1899] 1 QB 794.

182 Cooper (Inspector of Taxes) v Stubbs [1925] 2 KB 753.

183 Arbitraging between the three exchanges was no doubt an aspect of his dealings.

184 n 182 above, 763.

185 Barnett v Sanker (1925) 41 TLR 660.

186 Woodward v Wolfe [1936] 3 All ER 529, 533-4.
} 
The shadow cast by the Gaming Act could be avoided in the drafting of exchange rules and hence of the standard form contracts between members and those dealing through them on the exchanges.

\section{CONCLUSION}

Apart from some writing on the stock market ${ }^{187}$ and local markets, ${ }^{188}$ English lawyers have not generally speaking used the market as a category for analysis. A notable exception is Professor Sir Roy Goode, who as well as discussing the characteristics, functions and legal status of the rules of markets, has also advanced a thesis about what he calls 'the legal power of the market'. By this he means that since the consequences of not accepting a market's perception of the legal nature and incidents of its dealings could be catastrophic in a major market, in particular because of the loss of confidence, it would be surprising indeed if the courts were insensitive to the need to uphold reasonable business practice when not otherwise constrained by rules of positive law'. ${ }^{189}$ In his view this results in a market often being able to establish law through practice - 'to pull itself up by its own legal bootstraps' - although he does identify instances where courts have not upheld commercially sensible market transactions. ${ }^{190}$

Independently of Goode, Professor Hugh Collins has advanced an argument about what he calls club markets. ${ }^{191}$ These are constituted by a group of traders for their mutual protection and are based predominantly upon trust and non-legal sanctions. A characteristic of a club market is rules, which participants must comply with if they are to retain their membership and hence right to trade. Contracts are made informally but upheld because of the high degree of trust. Once created club markets facilitate new transactions such as futures contracts in that case through standardised descriptions of a commodity, standardised contracts and a mechanism to enforce bargains. In Collins' view the law has proved incapable of doing this and plays a peripheral, maybe impotent, role. When market innovations are first litigated they are usually declared invalid although this does not appear to have any effect on their use, since their force rests upon nonlegal sanctions. ${ }^{192}$

187 Early works include R.E. Melsheimer, Law and Customs of the London Stock-Exchange (London: Sweet, 1879); B.E. Spencer Brodhurst, Law and Practice of the Stock Exchange (London: W. Clowes and Sons, 1897); A.P. Poley, History, Law and Practice of the Stock Exchange (London: Sir Isaac Pitman \& Sons, 2nd ed, 1911).

${ }^{188}$ E.g. J. Hill, 'Markets and the Common Law' (1985) 5 Legal Stud. 320. But see Sir William Holdsworth, A History of English Law vol 5 (London: Methuen, 1924) 85-100 on the law merchant and international markets.

189 R. Goode, Commercial Law (London: Penguin, 3 rd ed, 2004) 159.

190 ibid 160. See also R. Goode, 'The Concept and Implications of a Market in Commercial Law' (1990) 24 Israel LR 185, 200-4; R. Goode, Commercial Law in the Next Millennium (London: Sweet \& Maxwell, 1998) 38.

${ }^{191}$ H. Collins, Regulating Contracts (Oxford: Oxford University Press, 1999) 212-6.

192 ibid 218. 
There is much in the history of the London and Liverpool commodity markets which accords with the analysis advanced by Professors Goode and Collins. Markets like the Baltic Exchange and Liverpool cotton market began informally in the first part of the nineteenth century, with little in the way of rules governing transactions. Brokers issued bought and sold notes from an early period, which evidenced the contracts made on these markets. ${ }^{193}$ Otherwise practice became the established basis for acceptable conduct. With time practice was incorporated into rules and by the close of the nineteenth century had become more elaborate to cope with innovations like clearing houses and futures transactions. Trust was no doubt high between brokers and non-legal sanctions must have operated as a constraint on behaviour. Relatively little litigation occurred, not least because arbitration offered an expeditious method for settling disputes. Law had some bearing on market integrity but very much as a long-stop. Britain did not follow the path of market regulation of Germany or the United States. ${ }^{194}$

There are several glosses, however, which need to be placed on the arguments of Professors Goode and Collins. First, law was not irrelevant to the development of these commodity markets. Law entered in the way the markets were constituted and governed; the system of rules for transactions and how these were cleared and settled; the standard form contracts used for dealings; and the arbitration procedures devised for dispute settlement. Admittedly the legal implications of what was being done were hardly ever articulated and lawyers not regularly engaged in the work, at least until well into the twentieth century. Practical men, engaged in commodity transactions, devised practices and fashioned rules and contracts against a backdrop of law but often unconscious of its rules and without much contact with its practitioners or institutions. The crucial point is that English law allowed unregulated association and freedom of contract and were prepared to countenance developments like forward sales, set-off and novation of contracts.

Secondly, the courts were neither as obstructive as Professor Collins suggests nor as supportive as Professor Goode's colourful image of legal bootstraps implies. Unsympathetic they could certainly be: for instance, there was Lord Halsbury's assertion, in Cooke \& Sons $\mathrm{v}$ Eshelby that the law would not be altered to suit the convenience of the Liverpool cotton market and the rejection by the House of Lords of a well established practice on commodity markets in Robinson $\mathrm{v}$ Mollett. ${ }^{195}$ Equally the courts adopted a hands-off approach to the internal decisions of the trade associations responsible for operating markets and they steered a passage for speculative dealings around the rocks of the gaming legislation. 196 On the whole English courts were insulated from the waves of

\footnotetext{
193 See R. Cranston, 'The Rise and Rise of Standard Form Contracts. International Commodity Sales 1800-1970' in J. Ramberg (ed), Commercial Law Challenges in the 21st Century. Jan Hellner in Memorium (Iustus Forlag, Stockholm 2007).

${ }^{194}$ E. Loeb, 'The German Exchange At of 1896' (1897) 11 QJ Econ 388; H. Hirschstein, 'Commodity Exchanges in Germany', Annals, v.155, May 1931, 208.

$195 \mathrm{n} 48$ above, $7,11$.

196 ibid 5, 30-2.
} 
litigation washing into United States courts. So the chances for untoward decisions were fewer. Partly that is explicable by healthy systems of arbitration, partly by the limited category of speculators on the London and Liverpool commodity markets who were potential litigants if deals went wrong for them. Perhaps most importantly doctrinal obstacles were rarely insuperable: the response to Cooke \& Sons $\mathrm{v}$ Eshelby, quoted above, is just one of a number of examples of how they could be avoided in the drafting of standard form contracts and rules. The law proved a rare barrier to the pursuit of profit in their preferred way by the practical men working the London and Liverpool commodity markets. 